University of Tennessee Law

Legal Scholarship Repository: A Service of the Joel A. Katz Library

UTK Law Faculty Publications

$4-2020$

Criminalizing Immigrant Entrepreneurs (and their Lawyers)

Eric Franklin Amarante

Follow this and additional works at: https://ir.law.utk.edu/utklaw_facpubs

Part of the Law Commons 


\section{University of Tennessee College of Law}

From the SelectedWorks of Eric Amarante

April, 2020

\section{Criminalizing Immigrant Entrepreneurs (and their Lawyers)}

Eric Franklin Amarante, University of Tennessee College of Law 


\section{HEINONLINE}

DATE DOWNLOADED: Thu Jul 22 16:31:48 2021

SOURCE: Content Downloaded from HeinOnline

Citations:

Bluebook 21st ed.

Eric Franklin Amarante, Criminalizing Immigrant Entrepreneurs (and Their Lawyers), 61

B.C. L. REV. 1323 (2020).

ALWD 6th ed.

Amarante, E. ., Criminalizing immigrant entrepreneurs (and their lawyers), 61(4) B.C.

L. Rev. 1323 (2020).

APA 7th ed.

Amarante, E. (2020). Criminalizing immigrant entrepreneurs (and their lawyers).

Boston College Law Review, 61(4), 1323-1378.

Chicago 17th ed.

Eric Franklin Amarante, "Criminalizing Immigrant Entrepreneurs (and Their Lawyers),"

Boston College Law Review 61, no. 4 (April 2020): 1323-1378

McGill Guide 9th ed.

Eric Franklin Amarante, "Criminalizing Immigrant Entrepreneurs (and Their Lawyers)" (2020) 61:4 BC L Rev 1323.

AGLC 4th ed.

Eric Franklin Amarante, 'Criminalizing Immigrant Entrepreneurs (and Their Lawyers)' (2020) 61(4) Boston College Law Review 1323.

MLA 8th ed.

Amarante, Eric Franklin. "Criminalizing Immigrant Entrepreneurs (and Their Lawyers)."

Boston College Law Review, vol. 61, no. 4, April 2020, p. 1323-1378. HeinOnline.

OSCOLA 4th ed.

Eric Franklin Amarante, 'Criminalizing Immigrant Entrepreneurs (and Their Lawyers)'

(2020) 61 BC L Rev 1323

Provided by:

University of Tennessee College of Law Joel A. Katz Law Library

-- Your use of this HeinOnline PDF indicates your acceptance of HeinOnline's Terms and Conditions of the license agreement available at

https://heinonline.org/HOL/License

-- The search text of this PDF is generated from uncorrected OCR text.

-- To obtain permission to use this article beyond the scope of your license, please use: Copyright Information 


\title{
CRIMINALIZING IMMIGRANT ENTREPRENEURS (AND THEIR LAWYERS)
}

\author{
ERIC FRANKLIN AMARANTE
}

INTRODUCTION 1324

I. CRIMINAL ENCOURAGEMENT. 1328

A. "The Game of the Name" ................................................................................... 1328

B. Defining Impermissible Encouragement ............................................................. 1331

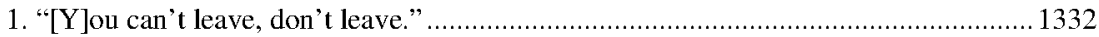

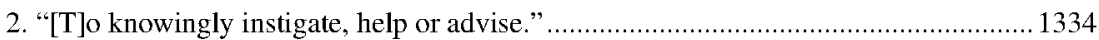

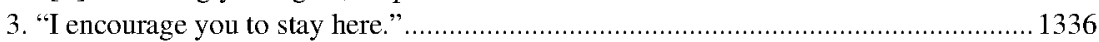

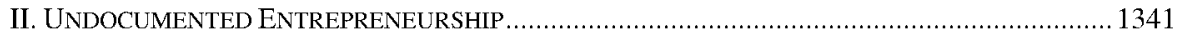

A. The Modern Undocumented Immigrant Entrepreneur .............................................. 1342

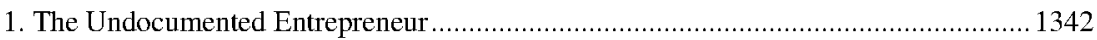

2. The Shift from Migrant Workers to Immigrant Workers.......................................... 1344

3. From Agriculture to Food Processing to Business Ownership.................................... 1348

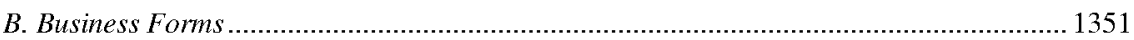

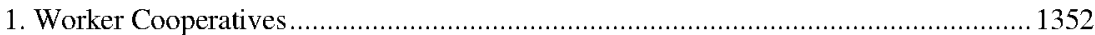

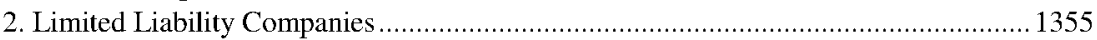

III. ENTREPRENEURSHIP OR ILLEGALLY EMPLOYING ONESELF? ......................................... 1356

A. The Legislative History of the Employment Restriction …............................................ 1357

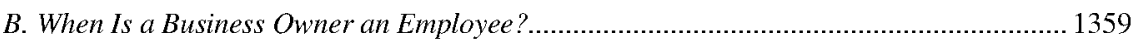

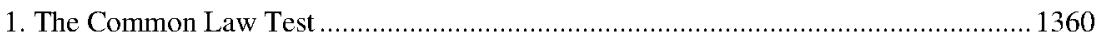

2. Applying the Common Law Test to LLCs and Worker Cooperatives .........................1362

3. Seeking Answers in Legislative History ................................................................. 1365

4. The Ultimate Effect on Entrepreneurs and Their Lawyers ...................................... 1366

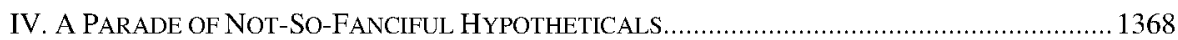

A. Criminalizing Legal Advice ............................................................................. 1368

B. Rendering State Laws and Policies Ineffective ........................................................... 1371

C. Public Universities and Private Corporations .......................................................... 1375

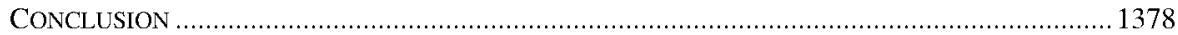




\title{
CRIMINALIZING IMMIGRANT ENTREPRENEURS (AND THEIR LAWYERS)
}

\author{
ERIC FRANKLIN AMARANTE*
}

\begin{abstract}
To escape the harsh conditions of work in agriculture or food processing plants, many undocumented immigrants turn to entrepreneurship for safer working conditions and better economic prospects. Transactional lawyers often help these entrepreneurs form limited liability companies or worker cooperatives. Unfortunately, this simple act might expose these lawyers to criminal liability. The Immigration Reform and Control Act of 1986 (IRCA) prohibits anyone from encouraging an undocumented person to reside in the United States. This prohibition has been construed to include everything from employing undocumented housekeepers to procuring falsified documents for citizenship applications, and some courts have even suggested that the encouragement restriction can reach legal advice. Although the Third, Fourth, Seventh, and Eleventh Circuits have construed IRCA's encouragement prohibition in a manner that avoids constitutional issues, the Ninth Circuit's decision in United States v. SinenengSmith found IRCA's encouragement prohibition unconstitutionally overbroad under the First Amendment. This Article argues that the courts that upheld the prohibition rewrote the statute, usurped the legislative authority of Congress, and ignored the chilling effect this statute has on wide swaths of protected and socially productive speech. On the other hand, the Ninth Circuit's decision signaled to lawyers and immigrant advocates that providing comfort, inspiration, or other forms of encouragement to undocumented people (including legal advice) will not be treated as a felony. By refusing to rewrite the statute, the Ninth Circuit's decision not only respects Congress's legislative authority, but it also represents sound policy by supporting undocumented entrepreneurship-a boon to the entrepreneur, the entrepreneur's family, and federal, state, and local economies.
\end{abstract}

\section{INTRODUCTION}

Some businesses, by their very nature, break the law. For example, an entrepreneur cannot take advantage of the nascent marijuana market without violating federal law, ${ }^{1}$ no matter how many times former Speaker John Boehner

(C) 2020, Eric Franklin Amarante. All rights reserved.

* Assistant Professor, University of Tennessee College of Law. I would like to recognize the generous feedback of Arléne Amarante, Wendy Bach, Michael Kagan, and Robert Statchen. I would also like to thank Johanna Kalb and the other participants of the 2019 Southern Clinical Conference work in progress session.

${ }^{1} 21$ U.S.C. $\$ 812(2018)$. 
appears in a pro-cannabis commercial. ${ }^{2}$ And if a business cannot avoid running afoul of the law, a lawyer should think twice before helping an entrepreneur form such a business. Such lawyers may be subject to ethical sanctions or criminal liability. ${ }^{3}$ But what if an entrepreneur asks a lawyer to help form a business to run a fruit stand, a lawn care business, or a home cleaning service? What could possibly be problematic about those businesses?

If the potential business owner is an undocumented immigrant, the answer is not clear. Although there is no law that prohibits undocumented people from owning businesses, a provision of the Immigration Reform and Control Act of 1986 (IRCA) criminalizes the employment of undocumented immigrants (the "Employment Restriction"). ${ }^{4}$ And under certain circumstances, a business owner may be deemed to also be an employee. Thus, when an undocumented business owner is also considered an employee, it would be impossible to operate an otherwise legal endeavor without violating the law. As a result, the operation of a fruit stand, a lawn care business, or a home cleaning service may be as unlawful under federal law as operating a marijuana dispensary.

Nonetheless, unlike with the sale of marijuana - which cannot be done without violating federal law - an owner of a fruit stand is not always deemed to be an employee. Immigrants and immigrant advocates have explored structuring certain legal entities, often worker cooperatives or limited liability com-

\footnotetext{
${ }^{2}$ See Iris Dorbian, Looking to Make Millions from Cannabis? Ex-House Speaker Boehner Will Tell You How, FORBES (Oct. 19, 2018), https://www.forbes.com/sites/irisdorbian/2018/10/19/lookingto-make-millions-from-cannabis-ex-house-speaker-boehner-will-tell-you-how/\#6d342b817c52 [https://perma.cc/74PE-X7L8] (discussing Boehner's online presentations targeted at an audience of cannabis investors).

${ }^{3}$ Helia G. Hull, Lost in the Weeds of Pot Law: The Role of Legal Ethics in the Movement to Legalize Marijuana, 119 PenN St. L. Rev. 333, 348-51 (2014); see MOdel RULES OF Prof'L CONDUCT r. 1.2(d) (AM. BAR ASs'N, Discussion Draft 1983) (stating that a lawyer "shall not counsel a client to engage, or assist a client, in conduct that the lawyer knows is criminal or fraudulent"); Edward J. Roche, Jr., Federal Income Taxation of Medical Marijuana Businesses, 66 TAx LAw. 429, 476 (2013) (stating that "[a] lawyer or accountant who is considering providing tax advice to, or preparing the tax return of, a medical marijuana business must take into account the possibility that this may subject him or her to criminal liability" and citing 18 U.S.C. § 2(a) (2018) noting, "[w] hoever commits an offense against the United States or aids, abets, counsels, commands, induces or procures its commission, is punishable as a principal"); see also Brian Melley, Lawyers Handling Marijuana Business Operate in Hazy Legal Zone, INS. J. (Dec. 12, 2017), https://www.insurancejournal.com/ news/national/2017/12/12/473767.htm [https://perma.cc/9UBZ-F3VJ] (quoting Professor Sam Kamin as saying "[a]ny lawyer that goes into this should be aware that a literal reading of federal law permits such a [criminal] prosecution").

${ }^{4}$ See 8 U.S.C. \$ $1324 \mathrm{a}$ (a) (2018) ("It is unlawful for a person or other entity . . to hire, or to recruit . . . for a fee, for employment in the United States an alien knowing the alien is an unauthorized alien ....").
} 
panies (LLCs), in a manner that avoids characterizing owners as employees. ${ }^{5}$ This is possible due to the relatively complex interaction between the legal definition of "employees" and the rules governing worker cooperatives and LLCs. Due to this complexity, undocumented entrepreneurs are wise to seek legal assistance before forming such businesses. ${ }^{6}$

Luckily, many transactional lawyers are eager to help. ${ }^{7}$ Although transactional lawyers have long "felt helpless" in the face of the myriad injustices imposed upon undocumented people, ${ }^{8}$ they are perfectly suited to navigate the complex web of laws that governs undocumented entrepreneurship. ${ }^{9}$ The very knowledge needed - an intimate understanding of corporate governance, entity formation, and employment law-sits squarely in the expertise of transactional lawyers. As a result, many transactional lawyers have helped undocumented immigrants structure businesses in a manner that avoids IRCA's Employment Restriction.

Although such lawyers may successfully avoid their client's potential liability under IRCA's Employment Restriction, a lawyer in this practice would be wise to review another section of IRCA, which makes it a felony to "encourage [] . . . an alien to . . reside in the United States" (the "Encouragement Restriction"). ${ }^{10}$ This language, on its face, criminalizes any efforts to encourage undocumented people and is broad enough to potentially criminalize a transactional lawyer's advice on how to structure a business in a manner that avoids IRCA's Employment Restriction. In fact, some prosecutors have argued that legal advice is covered by this statute. ${ }^{11}$ Thus, IRCA's Encouragement Re-

${ }^{5}$ Cindy Carcamo, Immigrants Lacking Papers Work Legally-As Their Own Bosses, L.A. TIMES (Sept. 14, 2013), https://www.latimes.com/nation/la-xpm-2013-sep-14-la-na-ff-immigration-business20130915-story.html [https://perma.cc/5X8G-J3AA].

${ }^{6}$ But see id. (describing the experience of Carla Chavarria, an undocumented immigrant, with forming a business). The article notes:

At a workshop hosted by immigrant rights activists, Chavarria learned about these intricacies of labor law-and how to register as a limited liability company. "I didn't know it was possible," Chavarria said. "And it wasn't that hard." It was as easy as downloading the forms from the Internet, opening up a bank account and turning in paperwork to the state along with a $\$ 50$ fee.

Id.

${ }^{7}$ See Gowri J. Krishna, Growing the Resistance: A Call to Action for Transactional Lawyers in the Era of Trump, 7 TENN. J. RACE, GENDER, \& SOC. JUST. 206, 217-21 (2018).

${ }^{8}$ See id. at 207 (describing how transactional attorneys "felt helpless and at a loss for how to use their legal skills" to assist undocumented immigrants).

${ }^{9}$ See generally id. (outlining a variety of ways in which transactional attorneys have assisted undocumented immigrants).

${ }^{10} 8$ U.S.C. $\$ 1324(\mathrm{a})(1)(\mathrm{A})(\mathrm{iv})$.

${ }^{11}$ See United States v. Henderson, 857 F. Supp. 2d 191, 203 (D. Mass. 2012) ("[T] he government contended that an immigration lawyer would be prosecutable for the federal felony created by 
striction might dissuade lawyers from engaging in this advocacy in the absence of clear guidance from courts. ${ }^{12}$ Unfortunately, appellate court decisions on the application and reach of the Encouragement Restriction are at best uneven, and at worst, conflicting. ${ }^{13}$ Meanwhile, undocumented entrepreneurs and immigrant advocates are stuck in limbo as courts wrestle with the appropriate reach of IRCA's Encouragement Restriction.

This Article explores the potential criminal liability imposed by IRCA's Encouragement Restriction when a lawyer helps an undocumented entrepreneur form a business specifically designed to avoid IRCA's Employment Restriction. Part I discusses how courts have construed the Encouragement Restriction, including a detailed analysis of the Ninth Circuit's decision in United States v. Sineneng-Smith, which held that IRCA's Encouragement Restriction is unconstitutionally overbroad. ${ }^{14}$ Part II will discuss the phenomenon of undocumented entrepreneurship and the factors which make business ownership attractive to undocumented people. ${ }^{15}$ This Part also includes an exploration of preferred legal entities for such businesses. ${ }^{16}$ Part III discusses IRCA's Employment Restriction and explains why transactional lawyers structure such businesses as worker cooperatives and LLCs in a manner that avoids the restriction. ${ }^{17}$ Part IV turns to policy by arguing that a strict interpretation of IRCA's Encouragement Restriction not only affects immigrant entrepreneurship, but might also chill other legal advice to undocumented people. ${ }^{18}$ This Part closes with a discussion of some of the unintended consequences of adopting an expansive view of the Encouragement Restriction. ${ }^{19}$

\footnotetext{
$\S 1324(\mathrm{a})(1)(\mathrm{A})(\mathrm{iv})$ if he advised an illegal alien client to remain in the country because if the alien were to leave the alien could not return to seek adjustment of status.").

${ }^{12}$ See Brief for Amici Curiae Immigrant Defense Project \& the National Immigration Project of the National Lawyers Guild in Response to the Court's Order Dated September 18, 2017, at 1, United States v. Sineneng-Smith, 910 F.3d 461 (9th Cir. 2018) (No. 15-10614) ("Amici are concerned that the [Encouragement Restriction] can and will be used to criminalize and thwart advocacy on behalf of immigrants due to the provision's sweeping scope and uncertain reach.").

${ }^{13}$ Compare DelRio-Mocci v. Connolly Props. Inc., 672 F.3d 241, 249 (3d Cir. 2012) (requiring "substantial" support akin to "an affirmative act that serve[s] as a catalyst for aliens to reside in the United States"), with Sineneng-Smith, 910 F.3d at 467-68, 485 (holding the Encouragement Provision to be "unconstitutionally overbroad in violation of the First Amendment").

${ }^{14}$ See infra notes 20-121 and accompanying text.

${ }^{15}$ See infra notes $122-191$ and accompanying text.

${ }^{16}$ See infra notes 192-223 and accompanying text.

${ }^{17}$ See infra notes 224-293 and accompanying text.

${ }^{18}$ See infra notes 294-343 and accompanying text.

${ }^{19}$ See infra notes 294-343 and accompanying text.
} 


\section{CRIMINAL ENCOURAGEMENT}

This Part provides the background necessary to understand the Encouragement Restriction of the Immigration Reform and Control Act of $1986 .{ }^{20}$ Section A discusses relevant vocabulary and the rationale for selecting the terms "undocumented," "immigrant," and "people" rather than "illegal" or "alien." ${ }^{2 I}$ Section B discusses court decisions that interpret the meaning of impermissible encouragement per IRCA's Encouragement Restrictions. ${ }^{22}$

\section{A. "The Game of the Name" 23}

Before discussing IRCA's Encouragement Restrictions and the phenomenon of undocumented immigrant entrepreneurs, it is wise to take a moment to consider vocabulary. When referring to people who are physically present in the United States without proper documentation, this Article intentionally uses "undocumented" as opposed to "illegal," and will refer to "immigrants" or "people" as opposed to "aliens." The words used in immigration debates are fraught with meaning, prejudicial and otherwise. By way of example, consider that the federal law refers to people without appropriate documentation as "aliens." ${ }^{24}$ Despite the facially inoffensive definition of "alien" as someone "from another country," 25 many immigrant activists ${ }^{26}$ and governments (including the State of California) ${ }^{27}$ have taken steps to cease using "alien" to refer to people

${ }^{20}$ See infra notes $21-121$ and accompanying text.

${ }^{21}$ See infra notes $23-43$ and accompanying text.

${ }^{22}$ See infra notes 44-121 and accompanying text.

${ }^{23}$ See Steven Pinker, The Game of the Name, BALT. Sun (Apr. 6, 1994), https://www.baltimore sun.com/news/bs-xpm-1994-04-06-1994096202-story.html [https://perma.cc/H49S-Z8SK] (highlighting the importance of word choice and vocabulary as "language . . . relates to thoughts and attitudes").

${ }^{24}$ See 8 C.F.R. § 274a.1(a) (2020) (defining the term "unauthorized alien").

${ }^{25}$ See Jose Antonio Vargas, I'm Not an 'Alien,' L.A. TIMES (Aug. 13, 2015), https://www.latimes. com/opinion/op-ed/la-oe-0814-vargas-illegal-alien-20150813-story.html [https://perma.cc/8975-XM2G]. Vargas writes:

There are those who say that "alien" is a perfectly fine, neutral term, and that anyone who finds it offensive is playing word police and should just check the dictionary. The second definition, in Merriam Webster: "from another country." Sting's pop song, "Englishman in New York," joyfully repeats "I'm a legal alien" in the chorus. Ian Whitcomb, another English pop singer, wrote a memoir called "Resident Alien."

Id.

${ }^{26}$ See Lauren Gambino, 'No Human Being Is Illegal': Linguists Argue Against Mislabeling of Immigrants, THE GUARDIAN (Dec. 6, 2015), https://www.theguardian.com/us-news/2015/dec/06/ illegal-immigrant-label-offensive-wrong-activists-say [https://perma.cc/Y54Q-JYTU] ("“We don't call pedestrians who cross in the middle of the road illegal pedestrians,' said [UCLA Professor] Otto Santa Ana ....").

${ }^{27}$ See S.B. 432, 2015-2016 Leg., Reg. Sess. (Cal. 2015); see also Patrick McGreevy, Gov. Brown Doesn't Want California to Use This Word for Immigrants, L.A. TIMES (Aug. 10, 2015), https://www. latimes.com/local/political/la-me-pc-gov-jerry-brown-signs-bills-to-help-immigrants-20150810- 
in the country without proper documentation. ${ }^{28}$ This is because the word "alien," quite literally, exoticizes and otherizes those from foreign countries, and conscientious people have advocated to avoid its usage. ${ }^{29}$

For similar reasons, this Article will not use the word "illegal" to refer to people in the United States without proper documentation, nor will it use "illegal" as a modifier for "immigrant." The word "illegal," similar to "alien," carries a significant negative connotation. ${ }^{30}$ For this reason, the term has become disfavored by a number of major news outlets. ${ }^{31}$

To critics, these choices are merely an indulgence for the unduly sensitive and little more than a nicety for the thin-skinned. ${ }^{32}$ It is clear, however, that

story.html [https://perma.cc/L6SP-UJ22] (noting a bill that removed the word "alien" from California's labor code).

${ }^{28}$ See Vargas, supra note 25 ("“Alien' is now commonly considered a derogatory term for a foreign-born person and has very negative connotations. The United States is a country of immigrants who not only form an integral part of our culture and society but are also critical contributors to our economic success." (quoting state Senator Tony Mendoza)).

${ }^{29}$ See Emily Bazelon, The Unwelcome Return of 'Illegals, ' N.Y. TIMES MAG. (Aug. 18, 2015), https://www.nytimes.com/2015/08/23/magazine/the-unwelcome-return-of-illegals.html [https://perma. cc/F2HF-L9GB] ("The term of art that statutes and courts have used since the 18th century - 'alien'hardly bridges the gap. It comes from the Latin for 'of or belonging to others,' and was codified in the first federal law that addressed granting citizenship to foreigners ...."). Bazelon also points out that the history of its use betrays a racial component of the acceptability of certain "aliens" that is deeply offensive. See id. (noting that the first law to use this term "allowed for naturalizing only an 'alien' who was a 'free white person'").

${ }^{30}$ See id. (noting that this term "implies suspicion"); see also Dan Merica, Clinton Says Her Use of Term 'Illegal Immigrant' Was a 'Poor Choice of Words, 'CNN (Nov. 24, 2015), https://www.cnn. com/2015/11/24/politics/hillary-clinton-illegal-immigration-undocumented-immigrants/index.html [https://perma.cc/3YVJ-38US].

${ }^{31}$ See Drop the I-Word, RACE FORWARD: CTR. FOR RACIAL JUST. INNOVATION, https://www. raceforward.org/practice/tools/drop-i-word [https://perma.cc/U538-MGYT] (quantifying the use of "illegal immigrant" by The New York Times, The Washington Post, USA Today, and The Associated Press). The article noted:

Since officially dropping [the use of "illegal immigrant"] in 2013, The Associated Press has consistently been the best performer of these four major national outlets. While The Washington Post has steadily improved its coverage each year, it has also consistently been the worst offender of the four outlets studied. Although The New York Times never officially pledged to drop [the use of "illegal immigrant"], it has the second best record of the four outlets studie[d]. However, some of the publication's leading immigration reporters continue to use the term.

Id.; see also Stephen Hiltner, Illegal, Undocumented, Unauthorized: The Terms of Immigration Reporting, N.Y. TIMES (Mar. 10, 2017), https://www.nytimes.com/2017/03/10/insider/illegal-undocumentedunauthorized-the-terms-of-immigration-reporting.html [https://perma.cc/2PCG-ZHHR].

${ }^{32}$ See, e.g., Hans A. von Spakovsky, "Undocumented Immigrant" Is a Made-Up Term That Ignores the Law, HERITAGE FOUND. (July 30, 2018), https:/www.heritage.org/immigration/commentary/ undocumented-immigrant-made-term-ignores-the-law [https://perma.cc/YPX8-ZDVD] (" "Undocumented immigrant' is a politically correct, made-up term adopted by pro-illegal alien advocacy groups and liberal media outlets to obscure the fact that such aliens have violated U.S. immigration law and are in the country illegally."); see also Gene Demby, In Immigration Debate, 'Undocumented' Vs. 'Ille- 
many anti-immigrant advocates use the term "illegal" to dehumanize immigrants. This practice has become so commonplace that such advocates, bristling at the perception of creeping political correctness, have weaponized the use of "illegal" as a substitute for either "alien" or "immigrant" to signal an aggressively anti-immigrant political stance. ${ }^{33}$ For these reasons, the term "undocumented immigrant" has grown in favor among immigrant activists. ${ }^{34} \mathrm{In}$ deed, a number of activists have adopted "No One Is Illegal" as a rallying cry ${ }^{35}$ echoing Nobel Laureate Elie Wiesel's famous proclamation. ${ }^{36}$ It is in this spirit that this Article will refer to people in the United States without appropriate documentation as "undocumented." 37

This choice is not without its critics. ${ }^{38}$ In 2018, the Justice Department directed U.S. attorneys to use the term "illegal alien" rather than "undocumented immigrant" to more closely track the language of the relevant statutes. ${ }^{39}$ Fur-

gal' Is More Than Just Semantics, NPR (Jan. 30, 2013), https://www.npr.org/sections/itsallpolitics/ 2013/01/30/170677880/in-immigration-debate-undocumented-vs-illegal-is-more-than-just-semantics [https://perma.cc/J2JK-MSS9].

${ }^{33}$ See, e.g., von Spakovsky, supra note 32; see also Illegal Alien or "Undocumented Immigrant?," FED'N FOR AM. IMMIGR. REFORM (June 2009), http://www.fairus.org/issue/illegal-immigration/illegalalien-or-undocumented-immigrant [https://perma.cc/56P5-XJM5]. The article found:

The enablers of illegal aliens have engaged in a "political correctness" campaign in an attempt to suppress use of the legally recognized term "illegal alien" often asserting that "a person cannot be illegal." Their alternative term is "undocumented immigrant." This term blurs the distinction between legally admitted immigrants and those who have sneaked into the country or chosen to violate the terms of a legal entry. They have even gone so far as to advance their "political correctness" efforts in legal journals and in the courts.

Illegal Alien or "Undocumented Immigrant?," supra.

${ }^{34}$ See Demby, supra note 32 (“'Undocumented' and 'illegal' seem to be [about] signaling one's stance when it comes to immigration reform [rather] than . . . about characterizing the situation in a precise way" (quoting linguistic anthropologist Jonathan Rosa)).

${ }^{35}$ See NO ONE IS ILLEGAL-TORONTO, https://toronto.nooneisillegal.org [https://perma.cc/T3N7QHJR]. See generally JUSTIN AKERS CHACÓN \& MIKE DAVIS, NO ONE IS ILLEGAL: FIGHTING RACISM AND STATE VIOLENCE ON THE U.S.-MEXICO BORDER (2006).

${ }^{36}$ Elie Wiesel, The Refugee, 34 CrossCuRRENTS 385, 388 (Winter 1984-1985). Famously, Mr. Wiesel wrote: "You who are so-called illegal aliens must know that no human being is 'illegal.' That is a contradiction in terms. Human beings can be beautiful or more beautiful, can be right or wrong, but illegal? How can a human being be illegal?"' $I d$.

${ }^{37}$ The Supreme Court of California wrestled with this decision and came to the same conclusion. In re Garcia, 315 P.3d 117, 120 n.1 (Cal. 2014) (noting that "[a]lthough no shorthand term may be perfect," the U.S. Supreme Court concluded that this choice "avoids the potential problematical connotations of alternative terms").

${ }^{38}$ See id. at 135 (Chin, J., concurring) ("The term 'undocumented immigrant' is vague and is not used in the relevant statutes. It is also euphemistic, because it is unlawful to be in this country and to be undocumented in the sense in which defendants use the term.").

${ }^{39}$ Tal Kopan, Justice Department: Use 'Illegal Aliens,' Not 'Undocumented,' CNN (July 24, 2018), https://www.cnn.com/2018/07/24/politics/justice-department-illegal-aliens-undocumented/ index.html [https://perma.cc/JVU9-7EGR]. 
ther, even some institutions that recognize the problematic nature of the term "illegal immigrant" suggest that alternatives may not be appropriate. For example, while the New York Times urges its reporters to avoid the use of "illegal immigrant," it also warns reporters to temper use of "undocumented" because "it has a flavor of euphemism and should be used with caution outside quotation. ${ }^{40}$ Professor Steven Pinker argues that the use of such terms are a part of a self-defeating "euphemism treadmill" which ultimately results in negative associations with the new terms. ${ }^{41}$ Although such concerns have some merit, the use of the term "undocumented immigrant" reflects an attempt to respect the right of marginalized populations to self-identify. ${ }^{42}$ Even critics of euphemistic language might agree with this approach. Pinker, for example, in an essay castigating the spread of unbridled political correctness, said "[r]espect means treating people as they wish to be treated, beginning with names." 43

\section{B. Defining Impermissible Encouragement}

On its face, IRCA's Encouragement Restriction prohibits an absurd amount of activity. The statute imposes liability upon anyone who "encourages or induces [an undocumented immigrant] to come to, enter, or reside in the United States, knowing or in reckless disregard of the fact that such coming to, entry, or residence is or will be in violation of law." ${ }^{44}$ Given that impermissible encouragement could conceivably consist of little more than turning to an undocumented person and saying "I encourage you to stay in the United States," ${ }^{45}$ it is not outlandish to conclude that impermissible encouragement might include most forms of socially productive and desirable interactions. Part II of this Article discusses the potential reach of this prohibitionincluding how it might dissuade a lawyer advising an undocumented person to form a business - but first, this Section will explore how courts have construed this statute.

${ }^{40}$ Hiltner, supra note 31.

${ }^{41}$ Pinker, supra note 23.

${ }^{42}$ See Vargas, supra note 25.

${ }^{43}$ Pinker, supra note 23. To be sure, Professor Pinker did not argue that such respect automatically militates toward adopting politically correct terms. See id. Pinker noted that "[p]eople invent new 'polite' words to refer to emotionally laden or distasteful things, but the euphemism becomes tainted by association and the new one that must be found acquires its own negative connotations." $I d$. But regardless of the author's differences with Pinker's ultimate conclusions, the maxim that one ought to treat people "as they wish to be treated" is one upon which, hopefully, everyone can agree. See id.

448 U.S.C. $\$ 1324(\mathrm{a})(1)(\mathrm{A})(\mathrm{iv})$.

${ }^{45}$ See Sineneng-Smith, 901 F.3d at 479 (concluding that a person who makes such a statement would be "vulnerable to prosecution" under the statute's Encouragement Restriction). 
1. "[Y] ou can't leave, don't leave." 46

Perhaps the first decision to question the potential reach of IRCA's Encouragement Restriction in depth was the U.S. Court of Appeals for the Third Circuit's 2012 opinion in DelRio-Mocci v. Connolly Properties. ${ }^{47}$ In DelRioMocci, the court considered how IRCA's Encouragement Restriction applied to a landlord who sought out undocumented people as tenants under the assumption that undocumented people were less willing to file complaints about substandard housing. ${ }^{48}$ The court noted that successful claims under IRCA's antiharboring provision must include evidence that the defendant took actions that "substantially facilitated" an undocumented person's ability to remain in the United States. ${ }^{49}$ This must go beyond "general advice," and must amount to "some affirmative assistance that makes an alien lacking lawful immigration status more likely to enter or remain in the United States than she otherwise might have been." 50

In coming to this conclusion, the court expressed concern about the potential breadth of IRCA, stating that "reading the [Encouragement Restriction] too broadly risks rendering the remaining subsections of [IRCA] redundant or superfluous. ${ }^{.51}$ In this manner, the DelRio-Mocci court imposed a substantiality requirement to limit the reach of the Encouragement Restriction. ${ }^{52}$ The court found support for this interpretation by surveying other circuit decisions ${ }^{53}$ and ultimately concluded that the decisions only found liability "where defendants were personally involved in bringing aliens lacking lawful immigration status into the United States." ${ }^{54}$ To rule otherwise, the court said, would result in a statute that criminalized "giving any type of 'help' to an [undocumented immigrant], no matter how de minimis the assistance ...." 55

The DelRio-Mocci court recognized the potential breadth of the Encouragement Restriction and interpreted the statute in a narrow manner. As such, the DelRio-Mocci court's criticism of the statute is relatively subdued. This is not the case in United States v. Henderson, a 2012 U.S. District Court for the District of Massachusetts case that cited DelRio-Mocci extensively. ${ }^{56}$ Hender-

${ }^{46}$ Henderson, 857 F. Supp. 2d at 196.

${ }^{47}$ See 672 F.3d at $248-50$.

${ }^{48} I d$. at 244.

${ }^{49} I d$. at 248 .

${ }^{50} I d$.

${ }^{51} I d$. at 249.

${ }^{52}$ Id. at $248-50$.

${ }^{53}$ See Edwards v. Prime, Inc., 602 F.3d 1276, 1295 (11th Cir. 2010); United States v. Lopez, 590 F.3d 1238, 1249-52 (11th Cir. 2009); United States v. Fujii, 301 F.3d 535, 540 (7th Cir. 2002).

${ }^{54}$ DelRio-Mocci, 672 F.3d at 250.

${ }^{55}$ Id.

${ }^{56}$ Henderson, 857 F. Supp. 2d at 205-10. 
son involved the prosecution of Lorraine Henderson, a Field Office employee of the Department of Homeland Security, who repeatedly paid an undocumented woman, Fabiana Bitencourt, for cleaning services. ${ }^{57}$ Henderson made these payments with knowledge of Bitencourt's undocumented status and Henderson repeatedly encouraged Bitencourt to stay in the United States, telling her "if you leave they won't let you back" and "you can't leave, don't leave."58

Ultimately, and with great reluctance, the Henderson court held that these facts represented evidence sufficient to support a conviction under IRCA's Encouragement Restriction. ${ }^{59}$ But to say that the Henderson decision was delivered with great reluctance is something of an understatement. ${ }^{60}$ The court is quite transparent in its distaste for the "stern, solemn, and implacable sanctimony of the government," and admits it is "puzzled" by the government's relentless pursuit in light of "the pedestrian quality of the conduct that is at the core of this felony prosecution." 61

The government's argument in Henderson is fairly straightforward and appears to arise from a literal reading of the Encouragement Restriction. The government argued that "separately or together, Henderson's employment of, and advice to, Bitencourt were felonious." 62 In terms of the employment alone, the government's position was that "any homemaker who intermittently engages an individual cleaning lady to clean the homemaker's residence, knowing the cleaning lady is an illegal alien, would be prosecutable as a federal felon" under IRCA's Employment Restriction. ${ }^{63}$ This is not controversial. More upsetting was the government's argument that Henderson's simple advice- - which included the statements "if you leave they won't let you back" and "you can't leave, don't leave"-constituted a violation of the Encouragement Restriction. ${ }^{64}$

The Henderson court grudgingly agreed with the government's argument, but took steps to communicate its discomfort with the breadth of the Encouragement Restriction. The Henderson court was appalled at the notion that the prohibition might permit prosecutions of "immigration lawyers for advising illegal aliens regarding the circumstances under which they may pursue ad-

${ }^{57} \mathrm{Id}$. at $194-96$.

${ }^{58}$ Id. at $195-97$.

${ }^{59} \mathrm{Id}$.

${ }^{60}$ See id. at 193 ("I view the pursuit of this case to have been overkill through the improvident invocation of federal criminal felony process when alternative administrative sanctions more closely tailored to the significance of the misconduct are available and adequate.").

${ }^{61}$ Id. at $193-94$.

${ }^{62} I d$. at 200.

${ }^{63} \mathrm{Id}$. at 203 .

${ }^{64}$ See id. at 196, 203 ("The legal logic of the government's position is that such employment 'encourages' or 'induces' an illegal alien to reside in the country by providing an economic incentive to do so."). 
justment in status." 65 The Henderson court rejected any comfort found in the fact that such a case has not yet been pursued, noting that the lack of prosecutions can be attributed solely to the grace of prosecutorial discretion. ${ }^{66}$ The Henderson court ended its opinion with an observation that amounts to a warning: "The lessons of proportionate restraint while pursuing measured judgment, in the face of unreasoning outrage, require careful calibration of the level of culpability for modest misconduct. These are lessons often difficult to accept, master, and deliver." ${ }^{67}$ This thinly veiled condemnation of the government's unreasonably zealous prosecution doubled as a powerful argument that any attempted prosecution of activity that amounts to "encouraging or inducing," and nothing more, would be injudicious. Although the Henderson court viewed the government's prosecution as "improvident," and called the use of IRCA's Encouragement Restriction in this case "overkill," the court was forced to agree that the defendant's actions constituted impermissible encouragement under the plain meaning of the statute. ${ }^{68}$

\section{2. "[T] $]$ knowingly instigate, help or advise." 69}

A number of other circuits have wrestled with the potential reach of IRCA's Encouragement Statute, resulting in a slew of conflicting decisions that fail to provide a coherent definition of what, precisely, constitutes impermissible encouragement or inducement under IRCA. The U.S. Court of Appeals for the Ninth Circuit has followed the lead of DelRio-Mocci, holding that any successful prosecution for encouraging or inducing must include a substantial act. ${ }^{70}$ For example, in United States v. Thum, the Ninth Circuit held in 2014 that "escorting [an undocumented immigrant] from a fast food restaurant near the border to a nearby vehicle" would not constitute impermissible encouragement or inducement without an accompanying substantial action. ${ }^{71}$ The Thum court concluded that culpability requires "some action" that persuades the undocumented immigrant to "live in the country indefinitely," such as providing false identification documents for a citizenship application. ${ }^{72}$ In this

${ }^{65}$ See id. at $211-12$

${ }^{66}$ See id. at 212 ("To date [the government] understandably has not chosen to press the statute that far.").

${ }^{67} \mathrm{Id}$. at 214.

${ }^{68}$ See id. at 193 . The court makes no effort to hide its disdain, especially given the availability of "alternative administrative sanctions more closely tailored to the significance of the misconduct ....." Id.

${ }^{69}$ United States v. He, 245 F.3d 954, 957 (7th Cir. 2001).

${ }^{70}$ See United States v. Thum, 749 F.3d 1143, 1146-48 (9th Cir. 2014).

${ }^{71}$ Id. at 1144,1148 .

${ }^{72}$ See id. at 1148 (noting that other cases find that "a defendant 'encourages' an illegal alien to 'reside' in the United States when the defendant takes some action 'to convince the illegal alien to... 
manner, the Ninth Circuit followed the DelRio-Mocci court and heeded the warnings of Henderson, making it clear that any prosecutions for mere encouragement or inducement would not be upheld in the Ninth Circuit.

Thum echoes the holding in United States v. Oloyede, a 1992 U.S. Court of Appeals for the Fourth Circuit case that also required a substantial act to support any finding of impermissible encouragement. ${ }^{73}$ In Oloyede, the substantial act amounted to a defendant not only selling fraudulent documents, but also telling undocumented immigrants that the documents would allow them to remain in the United States and even travel back to their country of origin without negative consequences. ${ }^{74}$ Although the Oloyede court did not directly address whether the defendant's statements, on their own, would constitute impermissible encouragement, it strongly suggested that the provision of fraudulent documents was a determinative factor by noting that " $[\mathrm{t}]$ he selling of fraudulent documents and immigration papers . . . constitutes 'encourages' as that word is used in the statute." 75

In 2001, the U.S. Court of Appeals for the Seventh Circuit came to a similar conclusion in United States v. He, which upheld a conviction under the Encouragement Restriction. ${ }^{76}$ In $\mathrm{He}$, the defendant objected to the definition of "encourage" as "to knowingly instigate, help or advise," which was included in a supplemental jury instruction. ${ }^{77}$ Notably, this definition does not require any substantial act, leaving the jury free to determine that mere instigation, help, or advice would suffice for a conviction. Similar to the defendant in Lopez, however, the broadness of this definition was not necessary given the defendant's actions. Consider the fact that the defendant in $\mathrm{He}$ was accused of altering a passport, completing a falsified customs declaration form, and coaching an undocumented person to disclaim knowledge of the defendant. ${ }^{78}$ Such actions would certainly have fulfilled any substantially requirement and clearly involve more than mere instigation, help, or advice.

Thum, Oloyede, and He suggest something akin to a consensus with DelRio-Mocci, but other circuits have not followed suit. For example, in United States v. Lopez, the U.S. Court of Appeals for the Eleventh Circuit in 2009 up-

\footnotetext{
stay in this country,' or to facilitate the alien's ability to live in this country indefinitely") (citations omitted).

${ }^{73}$ See id. at 1146-48; United States v. Oloyede, 982 F.2d 133, 137 (4th Cir. 1992) ("[T]hey could continue to work in the United States[,] . . they would not be subject to the threat of imminent detection and deportation, and . . . they could travel back to their homeland without risk of being prevented from returning ....").

${ }^{74}$ See Oloyede, $982 \mathrm{~F} .2 \mathrm{~d}$ at 137.

75 See id.

${ }^{76} \mathrm{He}, 245 \mathrm{~F} .3 \mathrm{~d}$ at 957,961

${ }^{77}$ See id. at 957 (objecting on the grounds that these definitions were too broad).

${ }^{78}$ Id. at $956-57$.
} 
held a conviction for impermissible encouragement when the jury was instructed that "encourage" meant "to knowingly instigate, to incite to action, to give courage to, to inspirit, to embolden, to raise confidence, to help, to forward, and/or to advise." 79 The Lopez court held that merely "helping" can constitute criminal behavior, noting that "in other decisions in this circuit, the act[s] of 'helping' aliens come to, enter, or remain in the United States were deemed violations of [the Encouragement Restriction]." ${ }^{80}$ Although this language suggests that mere encouragement would support a successful prosecution under IRCA, the defendant's actions in Lopez would probably have satisfied the "substantial action" required by the Fourth and Ninth Circuits. In describing the defendant's actions, the Lopez court pointed out that the defendant "first had to take a boat to the Bahamas, refuel it, spend the night, pick up the aliens from an abandoned hotel, and then go to the marina and come back to the United States." 81 This litany of actions would appear to constitute a "substantial" act, but the Lopez court did not directly address the question.

Thus, the Seventh and Eleventh Circuits had the opportunity to come to a similar conclusion as the Third, Fourth, and Ninth Circuits and require the prosecution to show some substantial act before a conviction under the Encouragement Restriction would be appropriate. The fact that they did not might explain why the Ninth Circuit in Sineneng-Smith found that the Encouragement Restriction is unconstitutionally overbroad under the First Amendment. ${ }^{82}$

\section{3. "I encourage you to stay here." 83}

Evelyn Sineneng-Smith, the manager of an immigration consulting firm, repeatedly promised clients legal permanent residence through a long-defunct labor certification program. ${ }^{84}$ Sineneng-Smith's advice was largely directed at Filipino clients who were "unlawfully employed in the home health care industry." ${ }^{\prime 5}$ Despite knowing that the labor certification was not a viable route for permanent residency, Sineneng-Smith told clients she could ultimately help them obtain green cards through the program. ${ }^{86}$ Relying on her advice, two of the individuals she represented testified that "they would have left the country

\footnotetext{
${ }^{79}$ Lopez, 590 F.3d at 1247.

${ }^{80} I d$. at 1251 (citing United States v. Ndiaye, 434 F.3d 1270, 1278 (11th Cir. 2006)).

${ }^{81}$ Id. at 1252 .

${ }^{82}$ Sineneng-Smith, 910 F.3d at 485.

${ }^{83} \mathrm{Id}$. at 467 .

${ }^{84}$ See id. at 468 (noting that the Labor Certification program ceased to operate in 2001).

${ }^{85} I d$.

${ }^{86} \mathrm{Id}$.
} 
if Sineneng-Smith had told them that they were not eligible for permanent residence." 87

Recognizing the lack of guidance on the appropriate breadth of IRCA's Encouragement Restriction, the Ninth Circuit solicited amici curiae to address, among other questions, whether the Encouragement Restriction is "overbroad under the First Amendment, and if so, whether any permissible limiting construction would cure the First Amendment problem." 88 Ultimately, the court held that IRCA's Encouragement Restriction was unconstitutionally overbroad. ${ }^{89}$

\section{a. Constructing and Reconstructing the Encouragement Restriction}

A statute is impermissibly broad under the First Amendment if it reaches a substantial amount of protected speech, considered in light of the legitimate reach of the statute. ${ }^{90}$ On the other hand, a statute may survive an overbreadth challenge if the statute can be construed in such a manner that avoids "constitutional doubts." "Indeed, this is the course the DelRio-Mocci court took with the application of the substantiality requirement. ${ }^{92}$ In addition, this interpretation was likely on the mind of the government when it argued that the statute should be construed as to only apply to substantial acts. ${ }^{93}$ More specifically, the government argued that the Encouragement Restriction only applies when a person "(1) knowingly undertakes, (2) a non-de-minimis, (3) act that, (4) could assist, (5) a specific alien (6) in violating, (7) civil or criminal immigration laws." 94

\section{${ }^{87} \mathrm{Id}$.}

${ }^{88} I d$. at 469.

${ }^{89}$ Id. at 485; see also Lauren D. Allen, Illegal Encouragement: The Federal Statute That Makes It Illegal to "Encourage" Immigrants to Come to the United States and Why It Is Unconstitutionally Overbroad, 60 B.C. L. REV. 1205, 1233-39 (2019) (arguing that, under the overbreadth doctrine, IRCA's Encouragement Restriction is unconstitutional). Interestingly, the Fourth Circuit considered an overbreadth challenge to the Encouragement Restriction in United States v. Tracy. See 456 F. App'x 267 (4th Cir. 2011). The Tracy court held "that speech ... that constitutes criminal aiding and abetting does not enjoy the protection of the First Amendment." Id. at 272 (quoting Rice v. Paladin Enters., Inc., 128 F.3d 233, 242 (4th Cir. 1997)). The Ninth Circuit addressed this holding and pointed out the differences between aiding and abetting statutes and the Encouragement Restriction, highlighting the fact that "[i]ust two lines below [the Encouragement Restriction], Congress required that anyone who 'aids or abets the commission of any of the preceding acts' shall be punished as a principal." See SinenengSmith, 901 F.3d at 482 (quoting 8 U.S.C. \$ 1324(a)(1)).

${ }^{90}$ See United States v. Stevens, 559 U.S. 460, 473 (2010) ("[A] law may be invalidated as overbroad if 'a substantial number of its applications are unconstitutional, judged in relation to the statute's plainly legitimate sweep.'” (quoting Wash. State Grange v. Wash. State Republican Party, 552 U.S. 442,449 n.6 (2008))).

${ }^{91} \mathrm{Id}$. at 481

${ }^{92}$ See DelRio-Mocci, 672 F.3d at 241, 246-51.

${ }_{93}^{3}$ See Sineneng-Smith, 910 F.3d at 471.

${ }^{94}$ Id. 
The Ninth Circuit, however, was unwilling to follow the DelRio-Mocci court's interpretation. Although admitting that courts should follow the canon of constitutional avoidance - that is, to construct statutes in a manner that avoids raising questions of constitutional law-the Sineneng-Smith court held it would be inappropriate to do so when constitutional avoidance requires a court to effectively rewrite the statute in question. To do so, according to the court, "would constitute a serious invasion of the legislative domain, and sharply diminish Congress' incentive to draft a narrowly tailored law in the first place." 95 To adopt the government's construction - which, in effect, requires courts to add "an act requirement, a substantiality requirement, and a causation requirement" - would amount to redrafting the statute. ${ }^{96}$ Instead, the Ninth Circuit embraced the following, rather straight-forward, construction of the statute:

[T]o violate [the Encouragement Restriction], a defendant must knowingly encourage or induce a particular alien—or group of aliens - to come to, enter, or reside in the country in reckless disregard of whether doing so would constitute a violation of the criminal or civil immigration laws on the part of the alien. ${ }^{97}$

In a similar vein, the Sineneng-Smith court rejected the government's argument that the words "encourage" and "induce" refer to "specific actions that facilitate" an undocumented person's actions. ${ }^{98}$ This argument appeared to be designed to limit the prohibited activity to specific actions, as opposed to potentially protected expression. The Ninth Circuit, however, called this interpretation "strained," and instead adopted the plain meaning of the words because to do otherwise "would require [the court] to conclude that 'encourage' does not mean encourage." 99 To highlight the absurdity of the government's suggested construction, the Ninth Circuit asserted:

$[\mathrm{U}]$ nder the government's reading of the statute, it would argue that a mother telling an undocumented adult child "If you leave the United States, I will be very lonely. I encourage you to stay and reside in the country" would not subject the mother to prosecution. But, in this example, the mother is merely repeating the words of the statute in an attempt to get her child to stay. We think any reasonable

\footnotetext{
${ }^{95} \mathrm{Id}$. (quoting Stevens, 559 U.S. at 481).

${ }^{96} I d$. at 477 (citing DelRio-Mocci, 672 F.3d at 246-48).

${ }^{97}$ Id. at 472 .

${ }^{98}$ Id. at $474-75$.

${ }^{99}$ Id.
} 
person reading the [Encouragement Restriction] would assume that the mother's statement makes her vulnerable to prosecution . . . ${ }^{100}$

\section{b. The Encouragement Restriction Reaches Protected Speech}

Having settled on the proper construction of the Encouragement Restriction, the Ninth Circuit turned to the second prong of the overbreadth analysis: whether the statute, as properly construed, restricts protected speech. ${ }^{101}$ The court first considered whether such speech might be considered either incitement or speech integral to criminal conduct. If so, the restriction would be upheld as proper, as these are the two exceptions to the rule against overly broad speech restrictions. On the incitement issue, the court emphasized the temporal aspect of the exclusion, noting that the government may proscribe speech that is "directed to inciting or producing imminent lawless action and is likely to incite or produce such action." ${ }^{102}$ However, because the Encouragement Restriction "does not require that an [undocumented immigrant] imminently violate the immigration law," the Ninth Circuit held that "the incitement doctrine is a poor fit for this particular statute." ${ }^{103}$ The court conceded that the statute may reach some categories of speech "exempted from the First Amendment as incitement," but if any such speech exists, the court concluded that "it is an extremely narrow band of speech and does not significantly reduce the scope of the statute." 104

The court also rejected the argument that the restricted speech is integral to criminal conduct. For this argument, the government contended that the Encouragement Restriction prohibits actions that aid or abet criminal conduct. The court did not agree for a number of reasons. First, the court was troubled by the fact that the Encouragement Restriction applies to both civil and criminal violations. ${ }^{105}$ To hold that the Encouragement Restriction was valid as an aiding and abetting statute would represent an extension of the aiding and abetting doctrine to civil violations, an extension that the court was unwilling to

${ }^{100} \mathrm{Id}$. at 479 .

${ }^{101}$ See Virginia v. Hicks, 539 U.S. 113, 118-19 (2003) ("The showing that a law punishes a 'substantial' amount of protected free speech, 'judged in relation to the statute's plainly legitimate sweep,' suffices to invalidate all enforcement of that law, "until and unless a limiting construction or partial invalidation so narrows it as to remove the seeming threat or deterrence to constitutionally protected expression."' (quoting Broadrick v. Oklahoma, 413 U.S. 601, 615 (1973))).

${ }^{102}$ Sineneng-Smith, 910 F.3d at 480 (emphasis added) (quoting Brandenburg v. Ohio, 395 U.S. 444,447 (1969)).

${ }^{103} \mathrm{Id}$.

${ }^{104} \mathrm{Id}$.

${ }^{105}$ See id. at $479-82$. 
make. ${ }^{106}$ Second, the court highlighted the fact that normally, "aiding and abetting requires that a principal actually commit the underlying offense," but "[ $t$ ]here is no such requirement in [the Encouragement Restriction because] continuing to reside in the U.S. is not a criminal offense." 107 This is because, absent certain circumstances, residing in the United States without documentation is a civil violation. As a result, the court concluded that "assisting one to continue to reside here cannot be aiding and abetting a crime." 108 Third, and perhaps most convincing to the court, IRCA contains a specific provision that reaches anyone who "aids or abets the commission of any of the preceding acts." 109 Thus, the court was rather perplexed that the government would argue that the Encouragement Restriction should be upheld as an aiding and abetting statute when the statute itself contains a separate and explicit aiding and abetting provision.

Having settled upon the appropriate construction and concluding that the Encouragement Restriction neither prohibited speech designed to incite unlawful action nor speech integral to criminal conduct, the court discussed "whether the amount of protected speech the [Encouragement Restriction] restricts is substantial in relation to its legitimate sweep." "This inquiry requires a court to determine if there is "a realistic danger that the statute itself will significantly compromise recognized First Amendment protections of parties not before the Court." 111 On this point, the court was unequivocal: the potential reach of the Encouragement Restriction is absurdly broad and constitutionally unacceptable. To illustrate, the court, quoting an amicus brief, noted that the Encouragement Restriction would cover " "a loving grandmother who urges her grandson to over stay his visa,' by telling him 'I encourage you to stay." "112 The court also expressed concern that the statute might reach "marches, speeches, publications, and public debate expressing support for immigrants." ${ }^{113}$ The court imagined a hypothetical speaker who says:

I encourage all you folks out there without legal status to stay in the U.S.! We are in the process of trying to change the immigration laws, and the more we can show the potential hardship on people who have

${ }^{106}$ See id. at 482 (noting that the government "points to no case where a defendant was convicted for aiding and abetting a civil offense").

${ }^{107} I d$. at 480 (emphasis added).

${ }^{108} \mathrm{Id}$.

1098 U.S.C. $\$ 1324(\mathrm{a})(1)(\mathrm{A})(\mathrm{v})(\mathrm{II})$.

${ }^{110}$ Sineneng-Smith, 910 F.3d at 485.

${ }^{111}$ Id. at 483 (quoting Members of City Council of L.A. v. Taxpayers for Vincent, 466 U.S. 780 , 801 (1984))

${ }^{112}$ See id. (quoting an anecdote articulated in a submitted amicus brief).

${ }^{113} \mathrm{Id}$. at 484 . 
been in the country a long time, the better we can convince American citizens to fight for us and grant us a path to legalization . . . ${ }^{114}$

The court argued that even though such a speech would constitute neither incitement nor aiding or abetting, the plain language of the Encouragement Restriction would criminalize it. Such a conclusion would be unacceptable, as it would result in "[c]riminalizing . . . almost anyone willing to weigh in on the [immigration] debate." 115 This echoes the concern of the Henderson court, which noted that if "all the government needs to establish is that the defendant knowingly helped or advised the alien . . . the statute may be deployed to criminalize any action, however modest, which may be construed to involve any help or advice, however innocent in itself, to illegal aliens." 116

In this manner, the Sineneng-Smith court found the Encouragement Provision to be unconstitutionally overbroad. ${ }^{117}$ To support this decision, the court cited a number of imagined scenarios that the Encouragement Restriction would prohibit, including intimate conversations between family members ${ }^{118}$ and political speech. ${ }^{119}$ Wary of indulging in the "fanciful hypotheticals" discouraged by the Supreme Court, ${ }^{120}$ the Sineneng-Smith court stressed that these scenarios "are part of every-day discussions in this country where citizens live side-by-side with non-citizens." ${ }^{121}$ The Sineneng-Smith court did not, however, discuss the Encouragement Restriction's effect on a transactional lawyer's advice to an undocumented entrepreneur on how to properly form and operate his or her business. For many transactional attorneys, this activity is just as important to highlight as family conversations and political speeches.

\section{UNDOCUMENTED ENTREPRENEURSHIP}

This Part discusses the driving forces behind undocumented entrepreneurs in the United States and the business structures available for such entrepreneurs and their companies. Section A discusses economic opportunity and choice for undocumented immigrants in the United States and outlines reasons

114 Id.

$115 \mathrm{Id}$.

${ }^{116}$ Henderson, 857 F. Supp. 2d at 207 (alterations omitted) (quoting Fujii, 301 F.3d at 540).

117 Sineneng-Smith, 910 F.3d at 485.

118 See id. at 484-85 (discussing examples put forth in the amicus brief).

${ }^{119} \mathrm{Id}$. at 484 .

120 See United States v. Williams, 553 U.S. 285, 301 (2008) (bemoaning the "tendency of our overbreadth doctrine to summon forth an endless stream of fanciful hypotheticals"); Sineneng-Smith, 910 F.3d at $483-85$.

121 Sineneng-Smith, 910 F.3d at 483. 
they may choose to be entrepreneurs. ${ }^{122}$ Section B evaluates the business entity options available to these undocumented immigrant entrepreneurs. ${ }^{123}$

\section{A. The Modern Undocumented Immigrant Entrepreneur}

Immigrants represent an integral part of the U.S. economy. ${ }^{124}$ Given the long history of immigrant workers in the United States, this should be no surprise. ${ }^{125}$ Although precise numbers are difficult to discern, most scholars estimate that there are about 10.5 million undocumented immigrants currently living in the United States, ${ }^{126}$ the vast majority of whom are vital participants in our country's economy. ${ }^{127}$ Of most interest to this Article, a disproportionate number of undocumented immigrants have proven to be quite entrepreneurial; eight to ten percent of business owners are estimated to be undocumented immigrants. ${ }^{128}$

\section{The Undocumented Entrepreneur}

At first blush, entrepreneurship might seem to be an unlikely option for many undocumented people. Most states do not allow undocumented immigrants to obtain driver's licenses, leading one to think that a business license

122 See infra notes 124-191 and accompanying text.

123 See infra notes 192-223 and accompanying text.

${ }^{124}$ Krishna, supra note 7, at 208.

${ }^{125}$ See PANEL ON THE ECON. \& FisCAL CONSEQUENCES OF IMMIGRATION, THE ECONOMIC AND FisCAL CONSEQUENCES OF IMMIGRATION 35 (Francine D. Blau \& Christopher Mackie eds., 2017) ("The United States began collecting data on the numbers and origins of arrivals by ship in 1820 ... Based on [this] data series, at least 74 million immigrants have arrived in the United States since 1820.").

${ }^{126}$ See Jens Manuel Krogstad et al., 5 Facts About Illegal Immigration in the U.S., PEw RES. CTR. (June 12, 2019), https://www.pewresearch.org/fact-tank/2019/06/12/5-facts-about-illegal-immigrationin-the-u-s/ [https://perma.cc/5EAH-3MYF] ("There were 10.5 million unauthorized immigrants in the U.S. in 2017 ....").

${ }^{127}$ Krishna, supra note 7, at 209 (citing Jeffrey S. Passel \& D'Vera Cohn, Overall Number of U.S. Unauthorized Immigrants Holds Steady Since 2009, PEW RES. CTR. (Sept. 20, 2016), https:// www.pewresearch.org/hispanic/2016/09/20/overall-number-of-u-s-unauthorized-immigrants-holdssteady-since-2009/ [https://perma.cc/B8AL-GF4D]). Krishna noted:

The approximately eight million undocumented immigrants in the civilian labor force made up five [percent] of the total number of people in the U.S. working or unemployed and looking for work, as of 2014. A higher percentage of undocumented immigrant men (ninety-one percent) between the ages of eighteen and sixty-four were working or looking for work as compared to U.S.-born men (seventy-nine percent) and lawful immigrant men (eighty-four percent) of similar age.

Id.

${ }^{128}$ Michael Mastman, Note, Undocumented Entrepreneurs: Are Business Owners "Employees" Under the Immigration Laws?, 12 N.Y.U. J. LEGIS. \& PUB. POL'Y, 225, 225 (2008) (citing Julia Boorstin, Illegal Entrepreneurs; Maria Has No U.S. Visa, and Jose's Expires Soon. Yet They Own a Profitable California Factory, Pay Taxes, and Create Jobs., CNN MONEY (July 1, 2005), https://money. cnn.com/magazines/fsb/fsb_archive/2005/07/01/8265279/[https://perma.cc/NX5F-5X5F-5QDQ]). 
would be out of the question. ${ }^{129}$ Further, one might assume entrepreneurship to be impossible for many undocumented immigrants because successful entrepreneurship requires a certain minimum level of resources and networks. ${ }^{130} \mathrm{~A}$ number of successful entrepreneurs embrace and champion failure, ${ }^{131}$ but economic failure can only be absorbed by those with financial means. ${ }^{132}$ For this reason, entrepreneurship is not often a realistic option for many undocumented people because they do not have the resources required to take advantage of market opportunities. ${ }^{133}$ Two notable professors write:

It is simply unreasonable to expect that those below the poverty line could survive the losses that invariably accompany entrepreneurial endeavors. At a certain level of poverty, the choice is between feeding one's family and nurturing a business investment, and it is untenable to expect an entrepreneur to make a decision that results in a loss of food for her family. ${ }^{134}$

${ }^{129}$ See Gilbert Mendoza \& Chesterfield Polkey, States Offering Driver's Licenses to Immigrants, NAT'L CONF. St. LEGISLATURES (July 25, 2019), http://www.ncsl.org/research/immigration/statesoffering-driver-s-licenses-to-immigrants.aspx [https://perma.cc/8NLR-RA6C] ("Thirteen states and the District of Columbia enacted laws to allow unauthorized immigrants to obtain . . . driver's licenses.").

${ }^{130}$ Minda Zetlin, Do You Need a Wealthy Background to Be a Successful Entrepreneur?, InC. (July 22, 2015), https://www.inc.com/minda-zetlin/do-you-need-a-wealthy-background-to-be-a-successfulentrepreneur.html [https://perma.cc/HYS4-XNC2]. Zetlin found:

It costs an average $\$ 30,000$ to start a company and the vast majority of start-up funding comes from personal assets and investments by family or friends. In addition to start-up costs, founders have to run their ventures for some time without drawing a salary. So it's easy to see how having a substantial bank account, wealthy friends or relatives who are willing to bet on you, and maybe a family or spouse who'll support you for a while makes starting a business much more feasible.

$I d$.

${ }^{131}$ See Eric Franklin Amarante, The Perils of Philanthrocapitalism, 78 MD. L. REV. 1, 39 (2018). This article notes:

In defending his embrace of failure, [Bill] Gates once noted, "Success is a lousy teacher. It seduces smart people into thinking they can't lose." . . . [David] Callahan quoted Bill Ackman, a hedge fund investor and philanthropist, as being so "comfortable with failure" that he admitted "there is some new mistake we haven't yet made that we'll make in the future. But as long as we learn from it, it's fine."

Id.

${ }^{132}$ See Rashmi Dyal-Chand \& James V. Rowan, Developing Capabilities, Not Entrepreneurs: A New Theory for Community Economic Development, 42 HOFSTRA L. REV. 839, 843 (2014) ("[T]he best innovations of social entrepreneurs have been captured by individuals and groups above the poverty line and often outside the inner city.").

${ }^{133}$ See id. at 844 (noting that, because of their general financial status, most undocumented people are not "in a position to exploit the market in the way that entrepreneurship theory demands").

${ }^{134}$ Id. at 861. 
Given this reality, one might reasonably ask why so many undocumented people decide to start their own businesses. Depressingly, it is because they have no better option.

Unlike traditional entrepreneurs, who turn to entrepreneurship because they have identified an unexploited market opportunity, ${ }^{135}$ undocumented immigrants are driven to entrepreneurship because the alternatives are terribly unattractive. ${ }^{136}$ For this reason, undocumented immigrant entrepreneurs should be thought of as necessity entrepreneurs. ${ }^{137}$ A necessity entrepreneur is someone who starts a business because they lack alternative choices. ${ }^{138}$ This is in contrast to opportunity entrepreneurs, who make business choices based on their self-interested motivations. ${ }^{139}$ A necessity entrepreneur is one motivated by "survival," while opportunity entrepreneurs are driven by "the dream of wealth," ${ }^{140}$ a desire to not have a boss, ${ }^{141}$ or even simple boredom. ${ }^{142}$ Indeed, one might consider an undocumented immigrant entrepreneur to be the quintessential necessity entrepreneur because, as the next Subsection will illustrate, the U.S. legal regime prohibits traditional employment for undocumented people, leaving only poorly paid, unsafe, and undesirable opportunities. ${ }^{143}$

\section{The Shift from Migrant Workers to Immigrant Workers}

Although entrepreneurship may not represent "a viable basis for systemic poverty alleviation," 144 it is often the best option for undocumented immi-

${ }^{135}$ See id. at 855 . The article notes that the "entrepreneur's important quality of 'alertness to the existence of opportunities that have been overlooked,' and ability to exploit such opportunities sufficiently to provide new resources and wealth for herself and those whom she employed." Id. (quoting ISRAEL M. KIRZNER, PERCEPTION, OPPORTUNITY, AND PROFIT: STUDIES IN THE THEORY OF ENTREPRENEURSHIP 110-11 (1979)).

${ }^{136}$ See Eric Franklin Amarante, The Unsung Latino Entrepreneurs of Appalachia, 120 W. VA. L. REV. 773, 782-83 (2018).

${ }^{137}$ PAUL D. REYNOLDS ET AL., GLOB. ENTREPRENEURSHIP MONITOR, 2001 EXECUTIVE REPORT 4 , at $8(2001)$.

${ }^{138} \mathrm{Id}$.

${ }^{139} \mathrm{Id}$.

${ }^{140}$ Scott A. Hipsher, Theoretical View on Microenterprise Entrepreneurial Motivators, in CONTEMPORARY MICROENTERPRISE: CONCEPTS AND CASES 49, 51 (Joseph Mark S. Munoz ed., 2010).

${ }^{141}$ Jonathan Long, 60 Reasons Why Entrepreneurship Is Amazing, ENTREPRENEUR, https://www. entrepreneur.com/article/243389 [https://perma.cc/K3CU-SJZT].

${ }^{142}$ Jacob Serebrin, Facing Boredom and Limited Savings, Seniors Turn to Entrepreneurship, GLOBE \& MAIL (Oct. 18, 2016), https://www.theglobeandmail.com/report-on-business/small-business/sbmanaging/seniors-turn-to-entrepreneurship-with-younger-partners/article32374241/ [https://perma.cc/ NY9A-EWQP].

${ }^{143}$ See Amarante, supra note 136, at 774-75; Frank M. Fossen \& Tobias J.M. Büttner, The Returns to Education for Opportunity Entrepreneurs, Necessity Entrepreneurs, and Paid Employees, 37 ECON. EDUC. REV. 66, 70 (2013) ("[N]ecessity entrepreneurs would not be entrepreneurs if they had alternative employment options.").

${ }^{144}$ Dyal-Chand \& Rowan, supra note 132 , at 844. 
grants. The story of the undocumented entrepreneur cannot be told without a brief discussion of the evolution of immigration enforcement in the United States. More specifically, this Subsection will examine how migrant workers became immigrant workers.

Not too long ago, many undocumented workers spent as little time in the United States as possible. Migrant workers, working primarily in agriculture, would enter the United States to perform seasonal work and return to their home country in the off-season. ${ }^{145}$ From the migrants' perspective, the primary reason to come to the United States was to find work and few had any interest in more permanent residence. ${ }^{146}$ From the perspective of the United States, the agriculture industry required inexpensive labor. ${ }^{147}$ The solution was the Bracero Program, a temporary guest worker program that provided temporary legal status for around 4.6 million Mexicans to meet the agricultural labor needs of the United States. ${ }^{148}$ Bracero workers would work during harvest season and spend the balance of the year in their home countries. ${ }^{149}$

The recent debate concerning immigration makes it difficult to fathom that, historically, many migrants were not interested in permanent residence. ${ }^{150}$ This is, however, certainly true. ${ }^{151}$ In a study describing the migration patterns of farmworkers from a rural Mexican town in the late 1970s, migrants held permanents homes in Mexico where they returned seasonally to rest in between busy agricultural periods in the United States. ${ }^{152}$ Indeed, this study noted that "90 percent of the legal migrants ... returned from their last trip to the U.S. within 12 months of leaving . . . and most of these (71\%) returned in nine

145 Marielena Hincapié, Aqui Estamos y No Nos Vamos: Unintended Consequences of Current Immigration Law, in GLOBAL CONNECTIONS \& LOCAL RECEPTIONS: NEW LATINO IMMIGRATION TO THE SOUTHEASTERn UNITED STATES 89, 94, 103 (Fran Ansley \& Jon Shefner eds., 2009); see Philip Martin, Mexican Workers and U.S. Agriculture: The Revolving Door, 36 INT'L MigRATION REV. 1124,1127 (2002) ("The demand for hired workers in agriculture is seasonal-more workers are needed during some months of the year than others. . . . The migrant farm labor system depended on an army of workers willing to accommodate themselves to seasonality.").

${ }^{146}$ Josh Reichert \& Douglas S. Massey, Patterns of U.S. Migration from a Mexican Sending Community: A Comparison of Legal and Illegal Migrants, 13 INT'L MigRATION REV. 599, 600 (1979).

${ }^{147}$ Martin, supra note 145, at 1127.

${ }^{148} \mathrm{Id}$. at 1128. This program applied to workers from "North America, South America, and Central America, and the islands adjacent thereto." Id.

${ }^{149} \mathrm{Id}$. at $1128-29$. It is important to note that the Bracero Program was adopted over the strenuous objection of labor activists. The labor advocates were drowned out by calls to provide "food to win the war" in light of World War II. Id. The hollowness of this justification was made bare when the end of the war failed to bring a cessation of migrant farmworkers crossing the border. Id. The Bracero Program was not without its critics, but advocates made them politically palatable by tying food production to the U.S. efforts in World War II. Id.

${ }^{150}$ See Reichert \& Massey, supra note 146, at 606.

${ }^{151} I d$.

${ }^{152} I d$. at $600-01,613$. 
months or less." ${ }^{153}$ The study concluded that although a high number of migrants make the trip to the United States for work, these migrants do not aspire to permanently move to the United States. ${ }^{154}$ In something of a prediction of future immigration policy, the report pointed out that the migrants who returned to Mexico were those who were legally permitted to engage in the work, while those without permission (i.e., undocumented immigrants) were less likely to return to their homes in Mexico. ${ }^{155}$ These undocumented workers, representing a minority of the migrants, were more likely to spend as much time as possible in the United States. ${ }^{156}$ The authors attributed this to "the high risk of detection faced by [undocumented immigrants] while crossing the border" and emphasized the "clear incentive" to stay in the United States longer in order to "maximize earnings." 157 Thus, while certainly unintended, the enforcement of immigration laws resulted in undocumented immigrants spending more time in the United States, a practice that increased in the ensuing decades.

These unintended consequences were magnified by the Illegal Immigration Reform and Immigrant Responsibility Act of 1996 (IIRIRA), which made it much more difficult for migrants to cross the border at the beginning and end of each harvesting season. ${ }^{158}$ The intent of IIRIRA was to "curtail unlawful immigration" and punish employers who violated IRCA's Employment Restrictions. ${ }^{159}$ IIRIRA, however, not only failed to meet the intended goal of curbing immigration, but it also resulted in a number of unintended consequences. ${ }^{160}$ Undocumented immigrants were already incentivized to spend as much time as possible in the United States, but IIRIRA's "bars to reentry" made that incentive much more powerful. ${ }^{161}$ These bars to reentry required undocumented immigrants to wait a period of time-in some instances up to ten years-before they were permitted to reenter the United States. ${ }^{162}$ This is true even if the person would otherwise be qualified to enter. ${ }^{163}$ These bars to

153 Id. at 606.

${ }^{154}$ Id. at 600 .

${ }^{155} I d$. at 613 .

${ }^{156} \mathrm{Id}$.

${ }^{157}$ See id. at 613-14 ("In this way, an [undocumented immigrant] can send or bring home more money, and thereby put off the time when he must risk another crossing into the United States.").

${ }^{158}$ See Pub. L. No. 104-208, 110 Stat. 3009-546 (1996) (codified as amended in scattered sections of 8 and 18 U.S.C.).

159 See Hincapié, supra note 145, at 100.

${ }^{160}$ See generally id. (arguing that a holistic global perspective is required to properly understand and tackle the issue of immigration).

161 See IIRIRA § 301; see also Hincapié, supra note 145, at 103.

162 See IIRIRA \$ 301.

163 See id. If, for example, a person had a valid family or employment-based petition, IIRIRA's bars would apply. Id.; see also Hincapié, supra note 145, at 103. IIRIRA imposes a three-year bar upon any person who leaves the United States after more than 180 days of unlawful residence and a 
reentry are triggered when a person leaves the United States and tries to reenter, and therefore IIRIRA serves as a strong incentive for many undocumented people to simply remain in the United States. ${ }^{164}$ One scholar observes, "[b]ecause workers without papers find it more and more difficult to maintain their traditional commuting pattern across the border, they opt to bring their families and settle them permanently on the U.S. side." 165 Another scholar notes that this phenomenon is further explained by the rationale underlying the decision of many undocumented immigrants to stay in the United States by saying:

[A]n immigrant can avoid being subject to [IIRIRA's bars to reentry] if she never leaves the United States. Undocumented immigrants who dream of eventual citizenship or lawful permanent residence and who receive well-informed advice, soon learn that departing from the United States will quite likely delay or destroy their chances of achieving lawful status. In essence, the penalties created by IIRIRA have had the unintended consequence of locking in many undocumented people who do not want to risk triggering the bars. ${ }^{166}$

In sum, after decades of encouraging both lawful and unlawful migration for agricultural labor, the United States passed a series of laws that resulted in criminalizing the employment of undocumented people, disrupted the traditional migration patterns that permitted an immigrant to move back and forth between Mexico and the United States, and incentivized undocumented people to establish more permanent lives in the United States. ${ }^{167}$ As the next Subsection explains, once these former migrants were effectively trapped in the United States as immigrants, it became clear that continued work in agriculture was not a viable long-term profession.

ten-year bar for any person who unlawfully resides in the United States for over a year. Any violation of these bars results in a permanent bar. See IIRIRA \$ 240A.

${ }^{164}$ See IIRIRA $\$ 240$ A.

${ }^{165}$ Alejandro Portes, The New Latin Nation: Immigration and the Hispanic Population of the United States, in A COMPANION TO LATINA/O STUDIES 15, 18 (Juan Flores \& Renato Rosaldo eds., 2009).

${ }^{166}$ Hincapié, supra note 145, at 103-04.

${ }^{167}$ Although this Subsection argues that there are numerous reasons for an undocumented immigrant to avoid crossing the border, a significant number of workers continues to repeatedly cross the border to follow seasonal work. As a recent study notes, "large numbers [of undocumented immigrants] also move both ways across the U.S.-Mexico border throughout the year, sometimes staying for only a few months ...." Jeffrey S. Passel \& D'Vera Cohn, Mexican Immigrants: How Many Come? How Many Leave?, PEW RES. CTR. (July 22, 2009), https://www.pewresearch.org/hispanic/ 2009/07/22/mexican-immigrants-how-many-come-how-many-leave/ [https://perma.cc/F5PX-RYGJ]. The study also observes that "Mexican-U.S. migration also tends to be seasonal, with larger northbound flows in the spring and summer and larger southbound flows in the fall and winter." Id. 


\section{From Agriculture to Food Processing to Business Ownership}

Although the promise of agricultural work drew most undocumented immigrants to the United States, ${ }^{168}$ many immigrants do not view farm labor as a permanent or long-term option for a number of reasons. ${ }^{169}$ First of all, farm work is physically demanding. As described by a migrant farmworker, "[a]griculture is very heavy work ... [; w]e toil from sunrise until our bodies can't take any more." 170 The punishing nature of agricultural work might be best explained by the attrition rate of U.S. citizens who try their hand at farm work. ${ }^{171}$ According to one study, of the 143 U.S. citizens who started working in the fields during the 2012 harvest season in North Carolina, only ten completed the season. ${ }^{172}$ This rate of attrition-approximately $93 \%$-is even more alarming when one considers the relatively high unemployment rate of $9.52 \%$ at the time. ${ }^{173}$ Further, that year was not an anomaly. In 2011, when the unemployment rate was even higher at $10.51 \%$, only seven of 163 U.S. citizens completed the season, resulting in an attrition rate of $95.7 \% .{ }^{174}$ For these reasons, at least one farm owner openly preferred immigrant workers, saying that he considers U.S. citizens "the labor pool of last resort." 175

Perhaps the physically demanding work would be sufferable if the pay were commensurate with the difficulty of the labor. Unfortunately, farm work is notoriously poorly remunerated. ${ }^{176}$ Labor rights activist César Chávez famously described farm workers as,

${ }^{168}$ See Martin, supra note 145, at 1139 (noting that "rural Mexicans often begin their American journey in U.S. fields and farm-related industries such as meat and poultry processing").

${ }^{169}$ See id. at 1133 ("Most of the [workers authorized under IRCA's Special Agriculture Worker program] who were in their twenties in the late 1980s have moved out of farm work . . .").

${ }^{170}$ Brian Barth, The High Cost of Cheap Labor, MOD. FARMER (Feb. 21, 2017), https://modern farmer.com/2017/02/migrant-farm-workers-the-high-cost-of-cheap-labor/ [https://perma.cc/VX3EDLWB].

${ }^{171}$ Michael A. Clemens, P'Ship for a New Am. ECON. \& CTR. FOR Glob. Dev., InTernaTIONAL HARVEST: A CASE STUDY OF HOW FOREIGN WORKERS HELP AMERICAN FARMS GROW CROPS-AND THE ECONOMY 4-7 (2013), https://www.cgdev.org/sites/default/files/internationalharvest.pdf [https://perma.cc/9DCQ-NJ59].

${ }^{172} \mathrm{Id}$. at 10.

${ }^{173} \mathrm{Id}$.

${ }^{174} I d$.

${ }^{175}$ Barth, supra note 170 . The reasons farmers prefer immigrant labor are as predictable as they are hilarious. As one farmer said, "The one kid couldn't stop texting while he was on the plow. The other kid was just dense. How many times can you turn to someone and say, 'You know, you missed fruit on that plant?' A bunch of stuff rotted in the field." Id. (quoting a farmer from Valatie, New York).

176 See Steve Clapp, Fixing the Food System: Changing How We Produce and CONSUME FoOD 142 (2017) ("Farmworkers still have the lowest annual family incomes of any U.S. wage and salary workers ...."). 
involved in the planting and the cultivation and the harvesting of the greatest abundance of food known in this society. They bring in so much food to feed you and me and the whole country and enough food to export to other places. The ironic thing and the tragic thing is that after they make this tremendous contribution, they don't have any money or any food left for themselves. ${ }^{177}$

This bitter irony - that those who pick our fruits and vegetables cannot afford to buy sufficient food-is compounded by the seasonal nature of most agricultural work. ${ }^{178}$ Once harvest time has passed, the work in the fields dries up. Thus, not only does the work not pay well, but the work is intermittent. Of course, this seasonality was once a positive aspect of migrant farm work because it allowed migrant workers to return to their home countries during the off-season. Once IIRIRA established the reentry bars, however, immigrants who were virtually trapped in the United States began to seek more consistent, year-round work.

Without proper documentation, job opportunities outside of agriculture for immigrants are extremely limited. More often than not, the only available alternatives for undocumented immigrants are slaughterhouses, poultry plants, and various meat processing facilities. ${ }^{179}$ Although these jobs provide more consistent work, there is a reason these jobs are available: working in food processing plants is notoriously difficult, ${ }^{180}$ dangerous, ${ }^{181}$ and unpleasant. ${ }^{182}$

${ }^{177}$ Speech at Convention of International Union, United Automobile, Aerospace and A gricultural Implement Workers of America, Los Angeles, June 1974, in THE WORDS OF CÉSAR CHÁvEZ 79, 8687 (Richard J. Jensen \& John C. Hammerback eds., 2002) [hereinafter Speech at Convention of International Union].

${ }^{178}$ See CLAPP, supra note 176, at 142 ("Farm work is seasonal, strenuous, and dangerous . ..."); see also Speech at Convention of International Union, supra note 177, at 86-87.

${ }^{179}$ See Amarante, supra note 136, at 775, 781.

${ }^{180}$ See Peggy Lowe, Working 'The Chain,' Slaughterhouse Workers Face Lifelong Injuries, NPR (Aug. 11, 2016), https://www.npr.org/sections/thesalt/2016/08/11/489468205/working-the-chainslaughterhouse-workers-face-lifelong-injuries [https://perma.cc/AMM5-QDS8] (describing "punishing rates of production" resulting in "a lifetime of pain and physical problems"); see also Amarante, supra note 136, at 782 (stating that "[t]o make matters worse, workers in meat processing plants are routinely overworked and mistreated with reports of not only dangerous conditions, but also insufficient bathroom breaks that require workers to wear adult diapers").

${ }^{181}$ See U.S. GOV’T ACCOUNTABILITY OFFICE, GAO-16-337, WORKPLACE SAFETY AND HEALTH: AdDitional Data NeEDED to AdDRESS CONTINUED HaZARDS IN THE MEAT AND POULTRY INDUSTRY 21 (2016) (noting that employees in meat processing plants "fac[e] hazardous work conditions . . . including hazards associated with musculoskeletal disorders, chemical hazards, biological hazards from pathogens and animals, and traumatic injury hazards from machines and tools"); Michael Grabell, Exploitation and Abuse at the Chicken Plant, New YORKER (May 1, 2017), https:/www. newyorker.com/magazine/2017/05/08/exploitation-and-abuse-at-the-chicken-plant [https://perma.cc/ 9Q86-N3G3].

${ }^{182}$ See Tess Owen, Chicken Industry Workers Wear Diapers Because Bosses Allow No Breaks, NGO Says, VICE (May 11, 2016), https://www.vice.com/en_us/article/59ea3x/chicken-industry- 
Further, similar to most jobs available to undocumented immigrants, food processing plant positions pay extraordinarily low wages. ${ }^{183}$ Needless to say, in addition to these negatives, there is virtually no promise of advancement in these jobs. ${ }^{184}$

Thus, without authorization to work in the United States, the only choice presented to many undocumented immigrants is either the intermittent and poorly paid work on farms or the disgusting and dangerous work in food processing plants. It should therefore be no surprise that many immigrants look for other opportunities to support their families.

Faced with the choice of work on the farm or in the factory, and virtually prohibited from leaving the United States without forgoing future opportunities within the country due to IIRIRA, it is little wonder that many undocumented immigrants turn to entrepreneurship. Despite the fact that the entrepreneurship of many undocumented immigrants is far from glamorous, often consisting of domestic work or landscaping, "the preponderance of research in the area suggests that, even in its less attractive forms, self-employment offers immigrants better outcomes than other available options" and such entrepreneurs fare better economically. ${ }^{185}$

Given the improved economic prospects, undocumented entrepreneurship certainly provides a benefit for the individual entrepreneur and the entrepreneur's family. Compared to work in agriculture or food processing plants, business ownership provides more security, more safety, and markedly better financial prospects. But the benefits are not limited to the entrepreneur and his or her family; undocumented entrepreneurship has the potential to provide an

workers-wear-diapers-because-bosses-allow-no-breaks-ngo-says [https://perma.cc/WBB5-TZAD] (noting that a particular chicken plant "smells like a combination of chicken blood and bleach"); see also Grabell, supra note 181.

${ }^{183}$ See Amarante, supra note 136, at 785; see also Grabell, supra note 181 (noting that some workers tasked with rounding up chickens "are paid around $\$ 2.25$ for every thousand chickens[, and that t]wo crews of nine catchers can bring in about seventy-five thousand chickens a night," coming to $\$ 168.75$ an evening, presumably shared amongst nine workers).

${ }^{184}$ See Amarante, supra note 136, at 785. Specifically,

the jobs available to most immigrants do not provide much hope of economic advancement, which might convince immigrant workers to consider entrepreneurship. This is known as the blocked mobility theory, and studies show that "barriers in traditional labor markets and low human capital acquisition tend to be the driving forces behind the growth of self-employment activity among Latinos, especially the foreign-born."

$I d$. (quoting Bárbara J. Robles \& Héctor Cordero-Guzmán, Latino Self Employment and Entrepreneurship in the United States: An Overview of the Literature and Data Sources, 613 ANNALS. AM. ACAD. POL. \& SOC. SCI. 18, 21 (2007)).

${ }^{185}$ Stephanie A. Bohon et al., Mexican Self-Employment in Old and New Latino Places, in GLOBAL CONNECTIONS \& LOCAL RECEPTIONS: NEW LATINO IMMIGRATION TO THE SOUTHEASTERN UNITED STATES, supra note 145, at 199, 200. 
economic boon throughout the national economy. ${ }^{186}$ Immigrant participation in the workplace serves to bolster sorely needed revenue for the federal government, ${ }^{187}$ including tens of billions of dollars for the Social Security trust fund. ${ }^{188}$ Additionally, there is significant evidence that immigrant participation in the workplace helps on a local scale, with one report estimating that undocumented immigrants pay $\$ 11.64$ billion a year towards state and local taxes. ${ }^{189}$ This influx of revenue is particularly vital for small towns, where immigrantowned businesses have helped revitalize otherwise abandoned strip malls and commercial districts throughout the United States. ${ }^{190}$ Helping the economies of small towns not only keeps money circulating within the community, but it also provides local government with additional revenues through sales taxes, payroll taxes, and property taxes. ${ }^{191}$ In this manner, immigrant entrepreneurship helps improve both the lives of the individual business owners, as well as the local, state, and national economies.

\section{B. Business Forms}

It is difficult to ascertain the preferred legal entity for undocumented entrepreneurs. As private entities, states impose limited disclosure requirements, and tax information is not public. We might, however, make some educated assumptions about the preferred business entity choice of undocumented entrepreneurs. For example, it is likely that many undocumented entrepreneurs, like most entrepreneurs, decide against a formal legal entity and simply operate their busi-

${ }^{186} I d$.

${ }^{187}$ See Alexia Fernández Campbell, Trump Says Undocumented Immigrants Are an Economic Burden. They Pay Billions in Taxes., Vox (Oct. 25, 2018), https://www.vox.com/2018/4/13/17229018/ undocumented-immigrants-pay-taxes [https://perma.cc/Y4N-R5CS]. Campbell writes:

The most recent IRS data, from 2015, shows that the agency received 4.4 million income tax returns from workers who don't have Social Security numbers, which includes a large number of undocumented immigrants. That year, they paid $\$ 23.6$ billion in income taxes. That doesn't even include workers who paid taxes with fake Social Security numbers on their W-2 forms, which is also common.

Id.

${ }^{188}$ See id. (quoting Stephen Goss, chief actuary of the Social Security Administration, who said, "[w] estimate that earnings by unauthorized immigrants result in a net positive effect on Social Security financial status generally"); see also Krishna, supra note 7, at 210 (stating that "[t]he Social Security Administration reported in 2013 that undocumented immigrants worked and contributed as much as thirteen billion dollars in payroll taxes (including employers' contributions) to the Social Security trust fund in 2010").

${ }^{189}$ LiSA Christensen GeE et al., InSt. ON TAXation \& ECON. POLICY, Undocumented IMMIGRANTS' STATE \& LOCAL TAX CONTRIBUTIONS 1-2 (2017), https://itep.org/wp-content/uploads/ immigration2016.pdf [https://perma.cc/J53L-YP99].

190 See Amarante, supra note 136, at 774-75.

${ }^{191}$ Id. 
nesses as sole proprietorships. ${ }^{192}$ This is because sole proprietorships demand few legal formalities, have no filing requirements for formation, and are often the least expensive option for entrepreneurs. ${ }^{193}$ Further, given that many undocumented immigrants may lack access to legal advice, they are likely to start operating their business without legal formalities, which would normally result in the operation being treated as a sole proprietorship. ${ }^{194}$ But if an undocumented entrepreneur were to receive legal advice, it is unlikely that the business would remain a sole proprietorship. This is because any business that carries a modicum of potential liability would lead a rational entrepreneur to regard the liability protections of most legal entity forms with favor. ${ }^{195}$ Due to restrictions against employment of undocumented people, discussed in more detail below, many undocumented entrepreneurs opt to form either a cooperative or an LLC.

\section{Worker Cooperatives}

A worker cooperative is an ancient legal entity ${ }^{196}$ that has grown in favor of late. ${ }^{197}$ In short, worker cooperatives are "firms that are democratically owned and managed by their workers." 198 As succinctly described by one scholar, "a worker cooperative adheres to fundamental principles, such as voluntary and nondiscriminatory membership, democratic member control, equitable economic participation by members, and a commitment to ongoing member education." 199 These appealing characteristics have made worker cooperatives the entity of choice for many activists agitating to increase local ownership and control of businesses.

${ }^{192}$ See Choose a Business Structure, U.S. SMALl BUS. ADMIN., https://www.sba.gov/businessguide/launch-your-business/choose-business-structure [https://perma.cc/Y83U-EP4H] ("Sole proprietorships can be a good choice for low-risk businesses and owners who want to test their business idea before forming a more formal business.").

${ }^{193}$ Michael F. Crusto, Extending the Veil to Solo Entrepreneurs: A Limited Liability Sole Proprietorship Act (LLSP), 2001 COLUM. BUS. L. REV. 381, 387.

${ }^{194}$ See generally Justice Index 2016, NAT'L CTR. FOR ACCESS TO JUST., https://justiceindex.org/ [https://perma.cc/4476-MB2E] (providing data and information online regarding access to justice programs available throughout the country).

${ }^{195}$ See Crusto, supra note 193, at 383 ("Shielding a shareholder's personal assets from business liability is a quintessential element of corporate law.").

${ }^{196}$ See Robert Jackall \& Henry M. Levin, Work in America and the Cooperative Movement, in WORKER COOPERATIVES IN AMERICA 3, 3 (Robert Jackall \& Henry M. Levin eds., 1984) ("Since colonial times there has been a continuous history of worker cooperatives in the United States.").

${ }^{197}$ Eillie Anzilotti, More U.S. Businesses Are Becoming Worker Co-ops: Here's Why, FAST COMPANY (May 21, 2018), https://www.fastcompany.com/40572926/more-u-s-businesses-are-becomingworker-co-ops-heres-why [https://perma.cc/K9EZ-X95V].

${ }^{198}$ Jackall \& Levin, supra note 196, at 3.

${ }^{199}$ See Scott L. Cummings, Developing Cooperatives as a Job Creation Strategy for Low-Income Workers, 25 N.Y.U. REv. L. \& SOC. CHANGE 181, 185-86 (1999). 
Worker cooperatives have also proven to be quite popular for undocumented entrepreneurs. ${ }^{200}$ This is likely due to the fact that the worker cooperative entity boasts a number of inherent advantages that might be appealing to an undocumented worker. First of all, worker cooperatives provide democratic control over a workplace. Like many workers, undocumented workers are likely to be attracted to this governance structure. Indeed, undocumented workers might know more intimately the advantages of worker control, given that many of them were exploited by previous employers. ${ }^{201}$ A democratically controlled business is also attractive for workers of all stripes, as lay-offs or cuts in wages are often driven by investors or management interested in increasing profit margins. Worker cooperatives are less likely to experience such lay-offs or cuts in wages because there are no outside investors and management is conducted by the workers themselves. ${ }^{202}$ Thus, after covering the cost of operations and salaries, there is little concern for how much profit a particular endeavor makes. A worker cooperative additionally provides the potential upside of business ownership to laborers who have traditionally not been given such an opportunity. ${ }^{203}$ Further, because the workers are also tasked with running the business, there is an invaluable education component of being a member of a worker cooperative. ${ }^{204}$ Workers are often forced to learn "businessrelated skills such as accounting, marketing, management, and literacy," which are not often provided to laborers. ${ }^{205}$ Finally, a worker cooperative might also protect formerly vulnerable workers from exploitation by providing greater negotiating power. If a dishonest person owes money to an individual undoc-

${ }^{200}$ See Krishna, supra note 7, at 216 ("[Democracy at Work Institute's] mission is to 'expand the worker cooperative model to reach communities most directly affected by social and economic inequality, specifically people of color, recent immigrants, and low-wage workforces."'); see also Cummings, supra note 199, at 191-92 (discussing Las Domésticas, a cooperative of domestic workers); Mastman, supra note 128, at 241 (discussing the CleanHome cooperative).

${ }^{201}$ See Cummings, supra note 199, at 187 ("Workers exercise final decision-making authority over the way the work is organized, performed, and managed. They are given a stake in the business, and must work collaboratively in order to achieve success.").

${ }^{202}$ Id. Cummings further notes:

The formation of a cooperative business can also increase job security for workers who would otherwise be subject to market exploitation based on their vulnerable economic position. The collective nature of the cooperative enterprise provides mechanisms that foster this security. For example, the workers can provide each other mutual support in finding and maintaining stable jobs for all cooperative members.

Id.

${ }^{203} \mathrm{Id}$.

${ }^{204} \mathrm{Id}$.

${ }^{205}$ See id. ("By bearing the responsibility of running a business, the workers commit themselves to a continuing process of self-education .... In fact, many cooperatives are formed primarily to facilitate job training, and seek to attract seed money from foundations and government agencies to promote this mission."). 
umented person, they may threaten to report the person to immigration authorities as a way to avoid payment. This danger is lessoned in a worker cooperative, because the debtor "may be less inclined to withhold payment from a business entity with the power to resort to legal action to enforce its rights."206 An example of a successful and much celebrated worker cooperative is $S i$ Se Puede, a Brooklyn-based company that provides cleaning services. ${ }^{207}$ Formed in 2006, Si Se Puede is a women-owned worker cooperative where all members are immigrants. ${ }^{208}$ The organization is "designed to create living wage jobs that will be done in a safe and healthy environment." ${ }^{209}$ One member of Si Se Puede reported that after joining the cooperative, her hourly rate rose from $\$ 6.25$ an hour to $\$ 25$ an hour. ${ }^{210}$

${ }^{206}$ See id. (discussing "the formality of the cooperative business"). In addition, although beyond the scope of this Article, cooperatives present the opportunity to take advantage of certain preferential tax treatment. Briefly, cooperatives may deduct patronage dividends (amounts distributed to cooperative members on the basis of their work with the cooperative). See I.R.C. subtitle A, chapter 1, subchapter $\mathrm{T}$ (2018) (discussing the tax treatment of cooperatives and their patrons).

${ }^{207}$ About Us, Si SE PuEDE! WOMEN's COOPERATIVE, https://wecandoit.coop/about/ [https:// perma.cc/8A5Y-VKNU].

${ }^{208} \mathrm{Id}$.

${ }^{209}$ See id. (describing the organization as designed "to provide social support and educational opportunities for our members").

${ }^{210}$ Laura Flanders, How America's Largest Worker Owned Co-Op Lifts People Out of Poverty, Yes! MAG. (Aug. 15, 2014), https://www.yesmagazine.org/issue/poverty/2014/08/15/how-america-slargest-worker-owned-co-op-lifts-people-out-of-poverty/ [https://perma.cc/HR5H-6A6k]. For a $\$ 40$ monthly dues payment, workers receive $100 \%$ of the cleaning fees. Although the positives of worker cooperatives are numerous and the popularity of cooperatives is growing, there are some potential negative aspects of worker cooperatives as well. One can easily imagine how the democratic governance structure of worker cooperatives, although empowering for individual workers, might prove to be inefficient and challenging. See Cummings, supra note 199, at 188 ("A cooperative's democratic decision-making structure, while promoting collective action, may hamstring effective business management by hindering the cooperative's ability to respond swiftly to market opportunities. . . [T]here is a potential for intra-organizational disputes[,] . . requir[ing] a greater investment of resources to mediate member conflict, which also could reduce economic efficiency."); see also Alana Semuels, Getting Rid of Bosses, THE ATLANTIC (July 8, 2015), https://www.theatlantic.com/business/archive/ 2015/07/no-bosses-worker-owned-cooperatives/397007/ [https://perma.cc/T8ZZ-EMDD] (describing Black Star Co-op, a worker cooperative in Austin, Texas) ("[The Co-op] has been trying for some time to build a cover on its patio. . . . At some businesses, a $\$ 30,000$ patio cover might be able to be approved by a CEO and built within months. At Black Star, it has taken years. There were detailed purchase proposals and meetings, and the vote had to be unanimous among the 20 -member worker assembly."). Additionally, worker cooperatives organized with the help of service providers may find it difficult to sustain success once the support structure is removed. Finally, if a worker cooperative is dedicated to supporting an educational mission, there is a potential burden of training less-skilled members and an organization must practice patience with such members. See generally Cummings, supra note 199, at 187-88 (highlighting some of the challenges (as well as benefits) that may accompany a cooperative business structure). Discussing the pros and cons of cooperatives, Cummings notes that:

A significant drawback of the cooperative form is the potential for conflict between its job training and job creation missions. In particular, lower-skilled, less efficient workers-while gaining skills through their participation in the cooperative-are often una- 


\section{Limited Liability Companies}

Unlike the worker cooperative, which claims a heritage that predates the founding of the country, ${ }^{211}$ the LLC is a relatively new legal entity. It was invented in 1977 in Wyoming by a group of accountants and lawyers seeking to create an entity that incorporated the most attractive aspects of partnerships (e.g., pass-through taxation and flexible governance) ${ }^{212}$ and corporations (e.g., the limited liability protections). ${ }^{213}$ Once the tax treatment of this new form was clarified by the Internal Revenue Service in 1997, the LLC quickly became the most popular legal entity for new businesses. ${ }^{214}$ Of the numerous advantages of the LLC, it appears that flexibility is its primary attraction. Although the pass-through treatment is certainly an advantage, similar treatment is available to owners of S-Corps. ${ }^{215}$ An S-Corp, however, may not have more than one hundred shareholders, more than one class of stock, shareholders other than natural persons (or certain permitted entities), ${ }^{216}$ or any non-resident alien shareholders. ${ }^{217}$ In contrast, an LLC may enjoy the pass-through taxation of a partnership without any such ownership restrictions. ${ }^{218}$ Further, this flexibility extends to many aspects of the LLC, including the manner in which an organization is governed ${ }^{219}$ and the way members of the LLC are paid. ${ }^{220} \mathrm{Giv}$ -

ble to generate their share of business clients or participate on an equal footing with other members of the group. This can create resentment in the higher-skilled members, causing intra-group conflict. If low-skilled members continue to act as a drain on cooperative resources, they may jeopardize the economic viability of the group, and, in serious cases, precipitate the dissolution of the business.

Id. at 188.

${ }^{211}$ Jackall \& Levin, supra note 196, at 3.

${ }^{212}$ Eric H. Franklin, A Rational Approach to Business Entity Choice, 64 U. KAN. L. REV. 573, 586 (2016).

${ }^{213}$ See Daniel M. Häusermann, For a Few Dollars Less: Explaining State to State Variation in Limited Liability Company Popularity, 20 U. MIAMI BUS. L. REV. 1, 5-6 (2011) (noting that the LLC was "designed to be popular" for entrepreneurs).

${ }^{214}$ Franklin, supra note 212 , at 586.

21526 U.S.C. $\$ 1361$ (2018). If an owner of a corporation were interested in the pass-through taxation enjoyed by partnerships, they might opt to be treated as a "small business corporation" by making an S-election. See id.

${ }^{216}$ Certain trusts and tax-exempt organizations are permitted to be shareholders. See id. $\S 1361(\mathrm{c})(6)$.

${ }^{217}$ Id. $\$ 1361(\mathrm{~b})$.

${ }^{218} I d$.

${ }^{219}$ An LLC can, for example, opt to be managed by its members, an individual member, or an outside manager. See MASS. GEN. LAWS ch. 156C, § 24(a) (2020). The statute states:

Unless otherwise provided in the operating agreement, the management of a limited liability company shall be vested in its members. An operating agreement may provide for the management, in whole or in part, of a limited liability company by one or more managers, who shall hold office and have the duties set forth in the operating agreement. 
en the popularity of LLCs among entrepreneurs and the fact that pass-through taxation is available regardless of immigration status, it should be no surprise that many undocumented entrepreneurs are also attracted to the LLC form. ${ }^{221}$ Although there is no comprehensive study of undocumented immigrants who have formed LLCs, there are reports of immigrants operating graphic design businesses and political consultancies as LLCs. ${ }^{222}$ Indeed, the practice has become commonplace enough to support a private industry for helping undocumented immigrants form LLCs. ${ }^{223}$

\section{ENTREPRENEURSHIP OR ILLEGALLY EMPLOYING ONESELF?}

Increasing numbers of undocumented entrepreneurs forming businesses as worker cooperatives and LLCs have led to increased financial stability and more pleasant employment for undocumented people. The story of undocumented business ownership, however, is not as simple as the previous Section suggests, and there is a significant question as to the legality of an undocumented person owning a business. Or more precisely, given that the federal law prohibits the employment of undocumented people, an undocumented owner of a business might be violating federal law if the owner is deemed to be an employee of the business. ${ }^{224}$ As absurd as it sounds, an owner of a business would be guilty of employing an undocumented immigrant because the owner is employing him- or herself. Thus, the distinction between employment and ownership is of vital importance.

Id.

${ }^{220}$ An LLC may give preference to individual members or classes of members in terms of distributions. $I d$. $\$ 29$ (a) ("The profits and losses of a limited liability company shall be allocated among the members, and among classes or groups of members, in the manner provided in the operating agreement.").

${ }^{221}$ See Carcamo, supra note 5 ("It's unclear how many entrepreneurs [form LLCs]. Immigration experts say anecdotal evidence suggests interest in such businesses has grown in recent years as more states have adopted tougher illegal-immigration laws. But research is scant.").

${ }^{222}$ Id. Anecdotally, this Article's author has helped two undocumented immigrants open political consulting businesses to help politicians reach out to Latino voters.

${ }^{223}$ See, e.g., Robert Acevedo, Can an Illegal Immigrant Open an LLC Business?, FREEDOMTAX BLOG (Mar. 23, 2017), https://www.itinnumberonline.com/can-an-illegal-immigrant-open-an-llcbusinesse/ [https://perma.cc/63V8-WPM4]. The extraordinary flexibility of LLCs has resulted in an additional, and certainly unintended, consequence: LLCs may be structured to look very similar to cooperatives. See id. Because an organizer of an LLC has a virtually unfettered ability to dictate the structure of an LLC, there is nothing to stop an organizer from adopting the cooperative practice of, for example, democratic governance or equal economic treatment of members. See Cummings, supra note 199, at 205 ("The governing legal document of an LLC, the operating agreement, can be easily adapted to include cooperative principles.").

${ }^{224}$ See 8 U.S.C. \$ $1324 a$ (a)(1) (2018) ("It is unlawful for a person or other entity . . to hire, or to recruit . . . for a fee, for employment in the United States an alien knowing the alien is an unauthorized alien ...."). 
Section A of this Part reviews the legislative history of denying undocumented immigrants the right to work in the United States. ${ }^{225}$ Section B of this Part discusses when an undocumented immigrant business owner is also an employee in violation of the IRCA. ${ }^{226}$

\section{A. The Legislative History of the Employment Restriction}

The prohibition on employing undocumented immigrants, although widely known, is a fairly recent restriction. As pointed out by one professor, "[f]or a century before 1986, federal law permitted employers to hire undocumented immigrants." ${ }^{227}$ The legislative history of immigration statutes illustrates how modern immigration law evolved to focus on the activities of employers. ${ }^{228} \mathrm{In}$ contrast, early statutes criminalized those who were luring immigrants into the country with the promise of employment. For example, the Immigration Act of 1917 made it unlawful to "induce, assist, encourage, or solicit . . . any alien to come into the United States by promise of employment through advertisements." ${ }^{229}$ It is notable that this statute focused on the unlawful entry of immigrants, and did not specifically address employment of undocumented immigrants who might already reside in the United States. ${ }^{230}$ Following this theme, the 1952 Immigration and Nationality Act (the "1952 Act") established fines and imprisonment for anyone found guilty of "willfully or knowingly encourag[ing] or induc[ing], or attempt[ing] to encourage or induce, either directly or indirectly, the entry into the United States" of undocumented people. ${ }^{231}$ The 1952 Act also focused on the entry of undocumented immigrants, but farm owners expressed concerns that the "encourages or induces" language would cover agricultural hiring. Although the 1952 Act did not explicitly prohibit the employment of undocumented people that already resided in the United States, it is not unreasonable to conclude that paying someone for work might constitute unlawful encouragement or inducement. Recognizing the potential economic devastation that would befall the agricultural industry if employers were unable to take advantage of inexpensive undocumented labor, a group of Texas

${ }^{225}$ See infra notes 227-244 and accompanying text.

${ }^{226}$ See infra notes 245-293 and accompanying text.

${ }^{227}$ Michael J. Wishnie, Prohibiting the Employment of Unauthorized Immigrants: The Experiment Fails, 2007 U. CHI. LEGAL F. 193, 193.

${ }^{228}$ See, e.g., Immigration Act of 1917, Pub. L. No. 64-301, 39 Stat. 874, 879-80 (1917).

${ }^{229} \mathrm{Id}$.

${ }^{230}$ This may have been due to the fact that early twentieth century migration patterns for farmworkers involved returning to Mexico at the end of each harvesting season. See supra notes 145-157 and accompanying text.

${ }^{231}$ Immigration and Nationality Act, Pub. L. No. 82-414, § 274, 66 Stat. 163, 228 (1952). 
legislators "muscled something called the 'Texas Proviso' into law.", 232 The Texas Proviso made it clear that employment of undocumented people did not constitute encouragement or inducement and therefore was not prohibited by the 1952 Act. The practical result was that employers of undocumented people were told: "Forget the law. You'll still get your cheap labor." 233

Needless to say, the 1952 Act did not quell concerns over unlawful immigration. Because the Texas Proviso was focused on protecting employers, the primary motivation for undocumented immigrants to enter the United States (i.e., jobs) remained in place. Thus, undocumented immigrants continued to cross into the United States to work, and policymakers concluded that any statute that ignored the employers would not be effective in curbing immigration. In this spirit, a few decades after the 1952 Act, the 92 nd Congress produced a series of bills that specifically criminalized the employment of undocumented immigrants. ${ }^{234}$ In its report, the House Judiciary Committee stated:

[T] he primary reason for the illegal alien problem is the economic imbalance between the United States and the countries from which aliens come, coupled with the chance of employment in the United States. Consequently, it is apparent that this problem cannot be solved as long as jobs can be obtained by those who enter this country illegally ....235

Following this logic, the House of Representatives passed several bills to penalize the employment of undocumented immigrants. Despite efforts during the Nixon and Ford administrations, none of these bills were able to pass in the Senate. ${ }^{236}$ Undaunted by the failures of his predecessors, President Carter also proposed restrictions on the employment of undocumented people. ${ }^{237}$ His efforts also failed. ${ }^{238}$ These repeated failures left the 1952 Act and the Texas Proviso intact for over three decades, imposing no consequences on employers who hired undocumented people.

This hypocrisy was finally put to rest in 1986 with the passage of IRCA, which addressed the primary shortcoming of previous laws by specifically prohibiting employers from knowingly hiring undocumented workers. ${ }^{239}$ Vio-

${ }^{232}$ Freedom Day, N.Y. TIMES (Oct. 19, 1986), https://timesmachine.nytimes.com/timesmachine/ 1986/10/19/138286.html?pageNumber=231 [https://perma.cc/8R6D-LGJW].

${ }^{233} \mathrm{Id}$.

${ }^{234}$ H.R. REP. No. 99-682, pt. 1, at 57 (1986), reprinted in 1986 U.S.C.C.A.N. 5649, 5661.

${ }^{235} \mathrm{Id}$.

${ }^{236} \mathrm{Id}$.

${ }^{237}$ Id. at 53 .

${ }^{238} \mathrm{Id}$.

2398 U.S.C. $\$ 1324 \mathrm{a}(\mathrm{a})(1)$. 
lations of this prohibition would result in fines, asset forfeiture, and even arrests of employers. ${ }^{240}$

Although the passage of IRCA addressed the hypocrisy of the Texas Proviso, it presented undocumented workers with a difficult choice: if the only way to provide food and shelter for your family is to secure work in the United States, you can either (i) forge or purchase fake documentation, ${ }^{241}$ or (ii) accept a job with an unscrupulous employer willing to violate IRCA. ${ }^{242}$ Such employers were often motivated to hire undocumented immigrants under the assumption that undocumented workers are unlikely to defend their rights in court. ${ }^{243}$ As noted above, some entrepreneurial undocumented immigrants have rejected these choices and opted to start their own business. Yet, under certain circumstances, IRCA's prohibition against employment of undocumented people might reach undocumented business owners, as the law sometimes considers business owners to be employees. ${ }^{244}$ Thus, even as a business owner, an undocumented entrepreneur might violate IRCA.

\section{B. When Is a Business Owner an Employee?}

Because IRCA was specifically drafted to target the employment of undocumented immigrants, it is not surprising that it does not address business ownership by undocumented immigrants. ${ }^{245}$ The relevant language of IRCA makes it "unlawful for a person or other entity . . to hire, or to recruit or refer for a fee, for employment in the United States an alien knowing the alien is an unauthorized alien." 246 The statute does not address business ownership and defines neither "hire" nor "employment." ${ }^{247}$ This silence is not the final word,

${ }^{240} \mathrm{Id}$.

241 See CHACÓN \& DAVIS, supra note 35, at 165 ("According to the New York Times, since the Immigration Reform and Control Act of 1986 set penalties for employers who knowingly hire undocumented immigrants, most have been forced to buy fake Social Security cards to obtain work.").

${ }^{242}$ Travis Putnam Hill, Big Employers No Strangers to Benefits of Cheap, Illegal Labor, TEX. TRIB. (Dec. 19, 2016), https://www.texastribune.org/2016/12/19/big-name-businesses-exploit-immigrant-labor/ [https://perma.cc/RY7G-4ZKE].

243 See id. ("Employment rights apply equally to all workers, regardless of their immigration status .... The problem is most undocumented workers don't know that, and employers may not know that. If they do know that, they will nevertheless use those workers' vulnerable immigration status to discourage them from enforcing their rights." (quoting Bill Beardall, executive director of the Equal Justice Center)).

${ }^{244}$ See, e.g., Employment Retirement Income Security Act of 1974, Pub. L. No. 93-406, 88 Stat. 829 (codified as amended in scattered sections of 26 and 29 U.S.C.); Americans with Disabilities Act, Pub. L. No. 101-335, 104 Stat. 327 (1990) (codified as amended at 42 U.S.C.).

2458 U.S.C. $\$ 1324 \mathrm{a}(\mathrm{a})(1)(\mathrm{A})$.

${ }^{246} I d$.

247 See id. (providing definitions for other terms in the statute such as "unauthorized alien"). 
however, because courts have construed a number of statutes in a manner that treats an owner of a business as an employee of the business.

This question - precisely who is an "employee"-is one that "has challenged scholars, jurists, and practitioners since the dawn of labor law." ${ }^{248}$ As with most legal puzzles, this issue's genesis lies in imprecise drafting as many statutes fail to provide adequate definitions. Further complicating matters is the fact that a litany of benefits and protections-including, for example, minimum wage laws, antidiscrimination protections, and Social Security retirement benefits - hinges on the existence of an employment relationship. ${ }^{249}$ With such high stakes, it is no wonder that this question is often intensely litigated.

\section{The Common Law Test}

Although intuition might suggest that an owner of a business cannot simultaneously be deemed an employee, this is a relatively common conclusion for many courts. For example, in Clackamas Gastroenterology Associates v. Wells, the Supreme Court held in 2003 that the owners of a medical practice may be treated as employees when determining whether the business was covered by the Americans with Disabilities Act (ADA) ${ }^{250}$ The ADA only applies to entities with fifteen or more employees and it is common for doctors in medical practices to be partners in the entity, as opposed to employees. ${ }^{251}$ The question before the Clackamas Court was whether a medical partnership with more than fifteen doctors (i.e., owners of a partnership) is subject to the

${ }^{248}$ Naomi B. Sunshine, Employees as Price-Takers, 22 LEWIS \& CLARK L. REV. 105, 106 (2018).

${ }^{249}$ Id. at $115-16$. Sunshine states:

Employment status determines whether a worker is entitled to the minimum wage and overtime under federal and state law. Employment status also determines whether a worker is covered under federal labor legislation, such as the National Labor Relations Act (NLRA) and its attendant rights to collective bargaining and protection from retaliation for concerted action. Only employees are protected by Title VII's antidiscrimination provisions. In addition, only employees are entitled to unemployment, worker's compensation, or Social Security retirement benefits. Although employers are generally not required to provide retirement benefits, if they do, these benefits are governed by the federal Employee Retirement and Insurance Security Act (ERISA), which applies only where an employer/employee relationship exists. The Affordable Care Act's employer health insurance requirements apply only to employees. In addition to labor and employment law, employment status matters for myriad substantive areas, such as tax, intellectual property, torts, and criminal law.

Id. (citations omitted).

${ }^{250}$ See 538 U.S. $440,448,450-52$ (2003) (holding that courts should refer to the common law control test to determine if an owner should be considered an employee).

${ }^{251}$ See Americans with Disabilities Act, 42 U.S.C. $\$ § 12101,12111$ (2018) (defining employer to mean "a person engaged in an industry affecting commerce who has 15 or more employees for each working day"). 
ADA. ${ }^{252}$ Interestingly, unlike IRCA, the ADA actually defined "employee," albeit in a maddeningly recursive manner. ${ }^{253}$ Under the ADA, an "employee" is "an individual employed by an employer." ${ }^{254}$ Given this lack of statutory guidance, the Clackamas Court turned to the common law. ${ }^{255}$

The Clackamas Court's resort to common law has precedent, as courts have a tradition of turning to common law in the absence of a clear statutory definition of "employee." "256 Clackamas cited the relative primacy of common law, noting that no particular entity form, internal agreement, or individual title shall sway the determination. ${ }^{257}$ The core of the common law control test is set forth in the Restatement (Second) of Agency, which defines the relationship between master and servant. ${ }^{258}$ Under the Restatement, a servant (i.e., an employee) is "a person employed to perform services in the affairs of another and who with respect to the physical conduct in the performance of the services is subject to the other's control or right to control." 259 The Restatement further clarifies this definition by providing a list of ten non-exhaustive factors to weigh. ${ }^{260}$ These ten factors, however, do not always control the outcome. ${ }^{261}$

${ }^{252}$ See Clackamas, 538 U.S. at $444-47$.

${ }^{253}$ See 42 U.S.C. $\S \S 12101,12111$.

${ }^{254}$ Id. $\$ \S 12101,12111(4)$. The Clackamas Court bemoaned that this definition is "completely circular and explains nothing." 538 U.S. at 444 (quoting Nationwide Mut. Ins. v. Darden, 503 U.S. 318, 323 (1992)). In Darden, the Court faced a similar failure of the Employment Retirement Income Security Act of 1974 to define "employee." See 503 U.S. at 319-20.

${ }^{255}$ See Clackamas, 538 U.S. at 444-47; Mastman, supra note 128, at 243 ("Confronting a question not fully answered by the statute or regulations, [the Office of the Chief Administrative Hearing Officer (OCAHO)] turned to federal common law for guidance. ... OCAHO's willingness to use employment law to define an edge of the employment relationship may make it more willing to do so in the future.").

${ }^{256}$ See Clackamas, 538 U.S. at 444-47; Darden, 503 U.S. 322-23 ("In the past, when Congress has used the term 'employee' without defining it, we have concluded that Congress intended to describe the conventional master-servant relationship as understood by common-law agency doctrine.") (citations omitted).

${ }^{257}$ See Clackamas, 538 U.S. at 450 ("The mere fact that a person has a particular title-such as partner, director, or vice president-should not necessarily be used to determine whether he or she is an employee or a proprietor. . . . Nor should the mere existence of a document styled "employment agreement' lead inexorably to the conclusion that either party is an employee."); see also Stephanie Greene \& Christine Neylon O'Brien, Who Counts?: The United States Supreme Court Cites “Control" as the Key to Distinguishing Employers from Employees Under Federal Employment Antidiscrimination Laws, 2003 COLUM. BUS. L. REV. 761, 780 (stating that the Clackamas "decision makes it clear that neither the form of business organization nor an individual's title determines coverage under the statutes").

${ }^{258}$ RESTATEMENT (SECOND) OF AGENCY $\$ 220$ (AM. LAw INST. 1958).

${ }^{259} I d . \$ 220(1)$.

${ }^{260} \mathrm{Id}$. $\$ 220(2)$. The definition provides that the ten factors to be considered are as follows:

(a) the extent of control which, by the agreement, the master may exercise over the details of the work; (b) whether or not the one employed is engaged in a distinct occupation or business; (c) the kind of occupation, with reference to whether, in the locality, the work is 
Indeed, the Clackamas Court identified a six-factor common law test to determine if a particular individual is an employee, and one could argue that the Clackamas decision reduced the common law test to a single factor: control. ${ }^{262}$ As Justice Ginsburg's dissent noted, the Clackamas majority opinion identifies "one of the common-law indicia of a master-servant relationship - control over the work of others engaged in the business of the enterprise - and accords that factor overriding significance." 263 Thus, Clackamas set precedent in turning to common law and in focusing on control in determining whether a business owner is an employee. ${ }^{264}$

\section{Applying the Common Law Test to LLCs and Worker Cooperatives}

In light of Clackamas, to determine if IRCA applies to an undocumented business owner, a court will use the common law control test and examine whether the undocumented immigrant owner has significant control. With sufficient evidence of control, the immigrant owner will not be deemed an em-

usually done under the direction of the employer or by a specialist without supervision; (d) the skill required in the particular occupation; (e) whether the employer or the workman supplies the instrumentalities, tools, and the place of work for the person doing the work; (f) the length of time for which the person is employed; (g) the method of payment, whether by the time or by the job; (h) whether or not the work is a part of the regular business of the employer; (i) whether or not the parties believe they are creating the relation of master and servant; and $(\mathrm{j})$ whether the principal is or is not in business.

Id.

${ }^{261}$ See Sunshine, supra note 248 , at 118 ("In practice, the common law test takes slightly different formulations across jurisdictions and agencies.").

${ }^{262}$ See Clackamas, 538 U.S. at 449-50 (describing the "six factors ... relevant to the inquiry whether a shareholder-director is an employee"); see also Mastman, supra note 128, at 249 ("The ultimate question under Clackamas is "whether the individual acts independently and participates in managing the organization, or whether the individual is subject to the organization's control.'").

${ }^{263}$ Clackamas, 538 U.S. at 452 (Ginsburg, J., dissenting). Interestingly, the Restatement of Employment Law provides some clarity on how ownership affects employment status by asserting that "[a]n individual who renders services to an enterprise that the individual controls through ownership is not as a general matter treated as an employee of that enterprise for purposes of the laws providing protections or benefits to or imposing obligations on employees." RESTATEMENT OF EMPLOYMENT LAW $\S 1.03 \mathrm{cmt}$. a (AM. LAW INST. 2015). Complicating matters, some statutes (e.g., the Fair Labor Standards Act of 1938, 29 U.S.C. $\$ \$ 201-219$ (2018)) specifically eschew the common law test and instead impose the "economic realities" test. See Baker v. Flint Eng'g \& Constr. Co., 137 F.3d 1436, 1440 (10th Cir. 2013). The economic realities test, used primarily to determine if a particular worker should be categorized as an independent contractor or an employee, consists of six factors, only one of which focuses on the common law control determination. The economic realities test consists of the following six factors: (i) the extent to which the work performed is an integral part of the employer's business; (ii) whether the worker's opportunity for profit or loss depends on the worker's managerial skill; (iii) the extent of the relative investments of the employer and the worker; (iv) whether the work performed requires special skills and initiative; (v) the permanency of the relationship; and (vi) the degree of control exercised or retained by the employer. Id.

${ }^{264}$ See Clackamas, 538 U.S. at 449-50. 
ployee. In Clackamas, for example, the Court noted that the owners of the medical practice were not employees because they "control the operation of their clinic, they share the profits, and they are personally liable for malpractice claims." ${ }^{265}$ Consider, however, the absurdity of trying to deduce if the owner of a single-member LLC is also an employee. In effect, one is forced to ask if an owner manifests sufficient control over him- or herself such that the law might justifiably consider the owner an employee.

Absurdity aside, the question for LLCs turns on whether the LLC is a member-managed or a manager-managed entity. In short, an LLC may be managed either by its members or by a manager (or managers), who may or may not be members. ${ }^{266}$ In a member-managed LLC, the "owners are engaged in the daily operation of the business" and "[e]ach member has the apparent authority to bind the LLC in transactions in the ordinary course of business." 267 This is in contrast to a manager-managed LLC, where the "operation of the entity is handled by a 'manager," and "[m]embers (who are not also managers) of a manager-managed LLC do not have the apparent authority to bind the LLC." ${ }^{268}$ Thus, if an LLC is member-managed, the member (i.e., the owner) has control over the operations of the entity. ${ }^{269}$

Although no court has directly ruled on the question of whether an undocumented owner of a business should be treated as an employee for the purposes of IRCA's Employment Restriction, there is some guidance by analogy. For example, with respect to tax treatment, the law has consistently held that owners of LLCs taxed as partnerships are not considered employees. ${ }^{270}$ Further, if a court were to apply the common law control test to an LLC owned and managed by an undocumented immigrant, there is a strong likelihood that an owner of a properly formed LLC will not be deemed an employee. One scholar argues:

$265 I d$ at 451 .

${ }^{266}$ See Robert R. Keatinge et al., The Limited Liability Company: A Study of the Emerging Entity, 47 BUS. LAW. 375, 385 (1992) ("Most of the LLC statutes provide for management directly by the members, although the statutes permit the parties to provide, by agreement, for centralized management."); see also MiCHAEL A. CHASALOW, EXPERIENCING BUSINESS ORGANIZATIONS 245 (1st ed. 2013).

267 CHASALOW, supra note 266, at 245.

268 Id.

${ }^{269}$ Likewise, if an undocumented immigrant formed a manager-managed LLC, the requisite level of control may not be evident. For example, if a non-owner is appointed as the manager, the LLC owner would be under the control of the manager and would appear to lack the requisite level of control (i.e., the owner would likely be deemed an employee).

${ }^{270}$ See Comm'r of Internal Revenue v. Robinson, 273 F.2d 503, 505 (3d Cir. 1959) ("A partnership is not an employer of the partners. It makes a return but the individual partners in their own personal returns account for their distributive shares of net income and net loss."). 
$[R]$ ulings from courts interpreting other federal employment laws suggest that so long as members of an LLC have a "proprietary" interest in the business - as demonstrated by their degree of ownership, their control over management decisions, and the extent to which their compensation is contingent on the business's profitsthey should not be considered "employees" of the LLC. ${ }^{271}$

Rulings in cases assessing employment under the Age Discrimination in Employment Act ${ }^{272}$ Title VII, ${ }^{273}$ and the Fair Employment and Housing Act are consistent with this assertion. ${ }^{274}$ Similarly, and in line with the Clackamas decision, in cases where an individual shows ownership, engages in governance, and receives profits based upon percentage ownership, the individual is not considered an employee. ${ }^{275}$ Under this analysis, it seems safe to assume that an LLC owner is not considered an employee so long as the owner has managerial control over the LLC's activities, a proprietary interest in the LLC's business, and compensation that is dependent upon the profits of the LLC.

Unfortunately, the answer as to whether a member of a worker cooperative is justifiably considered an employee is not as clear. If the common law control test is applied, the fact that worker cooperatives are owner-operated (i.e., owners have total control) strongly suggests an argument in favor of not treating worker cooperative members as employees. Indeed, a commonsense analysis of the structure of worker cooperatives suggests this conclusion. In this vein, some argue that because worker cooperative owners enjoy "equal control, the worker-owners do not have an employment relationship vis-à-vis the cooperative, and thus do not require work authorization." 276 Other commentators are less convinced, ${ }^{277}$ highlighting a handful of cases that have treat-

${ }^{271}$ Cummings, supra note 199, at 208.

${ }^{272}$ Fountain v. Metcalf, Zima \& Co., 925 F.2d 1398, 1399 (11th Cir. 1991).

${ }^{273}$ Serapion v. Martinez, 119 F.3d 982, 984-85 (1st Cir. 1997); Equal Emp’t Opportunities Comm'n v. Dowd \& Dowd, Ltd., 736 F.2d 1177, 1177-78 (7th Cir. 1984).

${ }^{274}$ Strother v. S. Cal. Permanente Med. Grp., 79 F.3d 859, 863 (9th Cir. 1996).

${ }^{275}$ Cummings, supra note 199, at 208 n.119.

276 See Krishna, supra note 7, at 217 ("Worker cooperatives, businesses owned by the workers themselves, have taken root as a means of job opportunity for immigrant workers, including for those without work authorization status." (citing CMTY. ENTER. PROJECT OF THE HARVARD TRANSACTIONAL LAW Clinics \& IMMigRant WORKER CTR. COllaborative, A LEGal OVERVIEW OF BUSINESS OWNERSHIP FOR IMMIGRANT ENTREPRENEURS IN MASSACHUSETTS (2015), http://clinics. law.harvard.edu/tlc/files/2015/09/TLC-Immigrant-Entrepreneurs-Overview.pdf [https://perma.cc/ R2BA-D76S])).

${ }^{277}$ See Cummings, supra note 199, at 203 ("[I]t is not clear whether members who work on behalf of the cooperative and receive patronage refunds would be considered employees under immigration laws."). It is further noted that "a review of the few cases that address the applicability of federal employment laws to cooperative corporation members tends to support the conclusion that members would be considered employees subject to IRCA." Id. at 203 n.104. 
ed members of worker cooperatives as employees under the Federal Labor Standards Act, ${ }^{278}$ state unemployment law, ${ }^{279}$ and a state's workers' compensation law. ${ }^{280}$ For these reasons, it is fair to say that the matter is unsettled.

\section{Seeking Answers in Legislative History}

The legislative history of IRCA clarifies that the Act was never intended to punish undocumented owners of businesses. IRCA's employer sanctions were passed to target employers who enticed immigrants to come to, or stay in, the United States and sought "to close the back door on illegal immigration so that the front door on legal immigration may remain open. The principal means of closing the back door, or curtailing future illegal immigration, is through employer sanctions." 281 The primary motivation for the law was the belief that undocumented workers were competing with U.S. citizens for jobs. ${ }^{282}$ At the time of IRCA's consideration, the unemployment rate in the United States was seven percent, and the legislative history notes that unemployment "is much higher among the minority groups with whom undocumented workers compete for jobs most directly." 283 The hope was that IRCA's employer sanctions would result in "ending the magnet that lures [undocumented workers] to this country." ${ }^{284}$ Beyond legislative intent, the Department of Justice's comments to the final rulemaking procedures of IRCA also emphasized that the focus of these prohibitions was to target "those persons and entities that hire, or recruit or refer for a fee" undocumented immigrants. ${ }^{285}$ These proclamations make it clear that IRCA's intended target was not the immigrant population, but the entities that hired immigrants. ${ }^{286}$ Thus, the legislative history strongly suggests

\footnotetext{
${ }^{278}$ See Goldberg v. Whitaker House Coop., Inc., 366 U.S. 28, 32 (1961) (holding that homeworker cooperative members were considered employees under the FLSA).

${ }^{279}$ Builders Commonwealth, Inc. v. Dep't of Emp't \& Econ. Dev., 814 N.W.2d 49, 52-54 (Minn. Ct. App. 2012).

${ }^{280}$ See Emp't Div. v. Surata Soy Foods, Inc., 662 P.2d 810, 811-12 (Or. Ct. App. 1983) (finding that coop members are employees under Oregon's workers' compensation law).

${ }^{281}$ H.R. REP. NO. 99-682, pt. 1, at 46, reprinted in 1986 U.S.C.C.A.N. 5649, 5650.

${ }^{282}$ See id. at 47 ("Undocumented aliens tend to come from countries with high population growth and few employment opportunities. The United States is not in a position to redress this imbalance by absorbing these workers into our economy and our population.").

${ }^{283} I$ I.

${ }^{284} \mathrm{Id}$. at 45-46. Interestingly, of particular concern was the effect immigration had on black unemployment. See id. at 47. A representative of the NAACP argued that "[m]any blacks are forced from employment rolls by the undocumented worker who is hired at a subminimum wage . . . The worker is consciously aware that he/she has no protection . . . and will accept 'starvation' wages to be employed in the United States." Id.

${ }^{285}$ Control of Employment of Aliens, 52 Fed. Reg. 16216-01 (May 1, 1987) (codified at 8 C.F.R. pt. 109, 274a).

286 See id.
} 
that IRCA's employer sanctions were adopted to address employers taking advantage of the perceived willingness of the undocumented workforce to accept low wages, thereby exacerbating unemployment of U.S. citizens. ${ }^{287}$ There is no suggestion that the employer sanctions were adopted to curtail entrepreneurship. To be blunt, an undocumented immigrant who starts a business to be selfemployed has not stolen a job from a U.S. citizen. Because IRCA's Employment Restriction was specifically designed to disincentivize employers from hiring undocumented immigrants, it would strain legislative intent to stretch its language to punish undocumented entrepreneurs under the technicality that the owner might also be considered an employee.

\section{The Ultimate Effect on Entrepreneurs and Their Lawyers}

At this point, it might be prudent to note that an undocumented person on the radar of immigration enforcement agencies would view this as a ridiculously theoretical discussion. To state the obvious, a violation of IRCA's Employment Restriction is likely to be quite low on the list of concerns for an undocumented entrepreneur. If immigration authorities were targeting a particular undocumented entrepreneur for deportation or removal, they would not have to rely upon a violation of IRCA's Employment Restriction. Rather, the immigration authorities could simply institute deportation proceedings on the basis that the person lacks appropriate documentation to remain in the United States, rendering moot any nuanced questions of employment versus ownership.

Despite the apparent picayune nature of this discussion, an undocumented immigrant might be wise to abide by IRCA's Employment Restriction, no matter how technical or slight. This is because a history of unlawful behavior, which could include IRCA violations, might be held against an undocumented immigrant when he or she applies for some relief. ${ }^{288}$ For example, in In re C-V$T$-, the Board of Immigration Appeals (BIA) held that, among other factors, "the presence of additional significant violations of this country's immigration laws" would weigh against an application for cancellation of removal. ${ }^{289}$ Thus, to the extent an undocumented immigrant maintains hope of one day obtaining legal status, it might be relevant to learn whether business ownership violates IRCA because it might be considered an "additional significant violation." 290 Further, as an example of immigration law's many contradictory signals, an

287 See H.R. REP. No. 99-682, pt. 1, at 57. The House Committee cautioned that IRCA's employment sanctions were not intended to apply "in the case of casual hires," which they defined as "those that do not involve the existence of an employer/employee relationship." Id. It is not entirely clear what this means, but at least one court has interpreted this to refer to domestic workers. See id.

${ }^{288}$ Mastman, supra note 128, at 228 (citing In re C-V-T-, 22 I. \& N. Dec. 7,11 (B.I.A. 1998)).

${ }^{289}$ In re $C-V-T-, 22$ I. \& N. Dec. at 11.

${ }^{290}$ See Mastman, supra note 128, at 228-29. 
undocumented immigrant might find that business ownership is beneficial in any future immigration procedure. At least one BIA decision seemed to hold a quite favorable view of an applicant's entrepreneurship. ${ }^{291}$

Mixed signals aside, the fact remains that any technical violation of IRCA's Employment Restriction is not likely to be a crucial question for many undocumented people. Nonetheless, the lawfulness of any particular business ownership might be relevant to the extent an undocumented immigrant consults a lawyer to help establish the business. If a lawyer were to help an undocumented immigrant navigate the bureaucratic odyssey of selecting an appropriate legal entity, the question of whether the undocumented immigrant would be an owner (i.e., no violation of IRCA) or an employee (i.e., a violation of IRCA) is of vital interest to the attorney. As this Section makes clear, the question is difficult to predict. Regardless, many lawyers form businesses for undocumented people in an effort to help their clients escape brutal working conditions and achieve greater financial freedom. ${ }^{292}$ These lawyers are, presumably, working under the assumption that the formation of LLCs and worker cooperatives does not violate IRCA's Employment Restriction. This conclusion is not outrageous, and given the unsettled state of the law surrounding the employment status of business owners, such lawyers can claim that they are operating under a reasonable interpretation of the law.

The IRCA Employment Restriction, however, is not the only matter such a lawyer ought to consider. As the discussion in Part I.B set forth, the Ninth Circuit is of the opinion that the plain language of the Encouragement Restriction "criminalizes the simple words - spoken to a son, a wife, a parent, a friend, a neighbor, a coworker, a student, a client-'I encourage you to stay here." 293 Thus, it is not outlandish to conclude that impermissible encouragement might include a lawyer's advice to (i) form an LLC or a worker cooperative, and (ii) structure the entity to avoid the possibility that the undocumented owner might be considered an employee. After all, the goal of such advice is to permit the undocumented person to secure safe, consistent, and humane employment, which would likely inform an undocumented person's decision to reside in the United States. Indeed, framed in this manner, it is hard to comprehend how this type of legal advice would not constitute impermissible encouragement. As such, risk-averse lawyers might be chilled from engaging in this

${ }^{291}$ See id. (noting that in In re Recinas, 23 I. \& N. Dec. 467 (B.I.A. 2002), "[t]he fact that the respondent owned a business which supported her children was of great importance to the Board [of Immigration Appeals], which emphasized that as a single mother, she was unlikely to find a comparably stable source of income in Mexico").

${ }^{292}$ See Krishna, supra note 7, at 216-17 (describing an effort to promote business ownership among undocumented immigrant entrepreneurs).

${ }^{293}$ United States v. Sineneng-Smith, 910 F.3d 461, 467 (9th Cir. 2018). 
type of representation. This discouragement harms not only undocumented immigrants, but also local, state, and federal economies.

\section{A PARADE OF NOT-SO-FANCIFUL HYPOTHETICALS}

The Ninth Circuit's concern that the Encouragement Restriction might reach intimate family conversations and political speech was enough to convince the court to find the provision unconstitutionally broad. By stopping there, the Ninth Circuit did not conduct an exhaustive discussion of each socially beneficial activity that might be chilled by the Encouragement Provision. It did not, for example, discuss how the Encouragement Restriction might convince a lawyer not to advise undocumented entrepreneurs. This Part will discuss additional activities that might be chilled by the Encouragement Provision. In the interest of heeding the Supreme Court's admonition not to indulge in "fanciful hypotheticals," state governments, corporations, or people actively engage. These activities include lawyers offering any advice to undocumented immigrants, let alone advice regarding business ownership. They also include certain state laws and policies, public educational institutions taking steps to attract a diverse student body, and laws protecting the health and safety of workers.

\section{A. Criminalizing Legal Advice}

Perhaps the most upsetting consequence of the Encouragement Provision is the potential to chill legal advice. Interestingly, the Supreme Court has not specifically addressed whether a lawyer's "advice to clients" is protected by the First Amendment. ${ }^{295}$ Although the issue remains unsettled, there are a number of compelling reasons to conclude that legal advice should be protected. ${ }^{296}$

${ }^{294}$ See Brief for Amici Curiae Immigrant Defense Project \& the National Immigration Project of the National Lawyers Guild, supra note 12, at 10 (citing United States v. Williams, 553 U.S. 285, 301 (2008) and bemoaning the "tendency of . . . overbreadth doctrine to summon forth an endless stream of fanciful hypotheticals").

${ }^{295}$ Eugene Volokh, Speech as Conduct: Generally Applicable Laws, Illegal Courses of Conduct, "Situation-Altering Utterances," and the Uncharted Zones, 90 CORNELL L. REV. 1277, 1283-84, 1343 (2005).

${ }^{296}$ Renee Newman Knake, Attorney Advice and the First Amendment, 68 WASH. \& LEE L. REV. 639, 645 (2011). Professor Knake notes:

Given the important nature of attorney advice, it may come as a surprise to learn that the First Amendment protection afforded to this category of speech is not clear. . . . Indeed, most First Amendment doctrine addresses speech intended for public consumption, while legal advice by definition entails communication intended for private consumption by clients, who then control its public dissemination. The Supreme Court has not directly ruled on the matter.

Id. 
First of all, the very nature of a just and democratic government relies upon the freedom of attorneys to provide unfettered advice to clients. ${ }^{297}$ This is not hyperbole, given that "litigation may well be the sole practicable avenue open to a minority to petition for redress of grievances." 298 One need not look further than the Supreme Court's seminal cases of Brown v. Board of Education and Obergefell v. Hodges to understand the import of this assertion. ${ }^{299}$ One scholar argues that "[a] necessary predicate to meaningful, effective litigation is the attorney's advice to her client about the client's legal rights and the proposed course of action." ${ }^{300}$ If litigation is the only recourse to ensure the protection of certain rights, any law that threatens to interfere with associated legal advice should be regarded with suspicion. ${ }^{301}$

Further, as noted by amici in United States v. Sineneng-Smith, the Encouragement Restriction could conceivably reach:

[A]n attorney who tells her client that she should remain in the country while contesting removal-because, for example, noncitizens within the United States have greater due process rights than non-citizens outside the United States, or because, as a practical matter, the government may not physically remove her until removal proceedings are completed. ${ }^{302}$

Although some might argue (indeed, many have) that the government has no interest in prosecuting lawyers for giving legal advice, the government has in the past demonstrated its willingness to bring these cases forward. ${ }^{303}$ In United States $v$. Henderson, for example, the government argued that immigration lawyers violate the Encouragement Restriction when they counsel their clients to remain in the country while their cases are determined. ${ }^{304}$ The Henderson prosecution also argued that a lawyer's advice that some relief might not be available

${ }^{297}$ See id. at $642-43$ ("The role of an attorney in navigating and, when necessary, challenging the law is a critical component of American democratic government.").

${ }^{298} I d$. at 643.

${ }^{299}$ See Obergfell v. Hodges, 135 S. Ct. 2584 (2015); Brown v. Bd. of Educ., 347 U.S. 483 (1954).

${ }^{300}$ See Knake, supra note 296, at 645 (referencing NAACP v. Button, 371 U.S. 415, 430 (1963)).

${ }^{301}$ Id. at 644. Professor Knake quotes Professor James Fischer, who warned that "legislative control 'over lawyer practice may come to erode the ability of lawyers to serve as a bulwark against the aggrandizement of government power vis à vis the individual."' Id. (quoting James M. Fischer, External Control Over the American Bar, 19 GEO. J. LEGAL ETHICS 59, 97 (2006)).

${ }^{302}$ Sineneng-Smith, 910 F.3d at 484-85.

${ }^{303}$ See id. at 485 (noting that "the government has already shown its intent to prosecute those citizens (attorneys or sympathetic lay persons) who give even general immigration advice" (citing United States v. Henderson, 857 F. Supp. 2d 191, 193 (D. Mass. 2012))).

${ }^{304}$ See Henderson, 857 F. Supp. 2d at 203 (noting that the government argued that "giving illegal aliens advice to remain in the United States while their status is disputed constitutes felonious conduct under [the Encouragement Restriction] because it constitutes encouragement or inducement under the statute"). 
if an undocumented client left the country is comparable to "a criminal defense lawyer who advises a client regarding the prospective robbery of a bank." 305

Two relatively recent cases might shed some light on the value that the Supreme Court places on legal advice. In Milavetz, Gallop \& Milavetz, P.A. v. United States, the Supreme Court in 2010 refused to uphold the U.S. Court of Appeals for the Eighth Circuit's decision to hold the Bankruptcy Abuse Prevention and Consumer Protection Act of 2005 constitutionally overbroad. ${ }^{306}$ The Eighth Circuit took issue with the statute's attempt to restrict lawyers from advising clients to incur additional debt before declaring bankruptcy. ${ }^{307}$ The intent of this statute is to prohibit a lawyer from advising a client to incur additional debt without any intent of honoring the obligation; however, it also could reach lawful advice. For example, the Eighth Circuit noted that a lawyer might be prohibited from providing "advice constituting prudent prebankruptcy planning that is not an attempt to circumvent, abuse, or undermine the bankruptcy laws." ${ }^{308}$ The Supreme Court disagreed, construing the statute to restrict advice that is designed to "manipulate the protections of the bankruptcy system." ${ }^{309}$ In a similar manner, consider how the Supreme Court might view an attorney's advice to an undocumented immigrant on the specific type of legal entity that would avoid the reach of IRCA's Employment Restriction. It is not unfathomable that the Supreme Court, citing Milavetz, could conclude that although such advice is not designed to promote unlawful activity (owning a business is, after all, legal), it is impermissibly designed to "manipulate" the dictates of IRCA.

At this point, it might be appropriate to point out that there are a number of lawyers providing advice to undocumented immigrants on various forms of business ownership, including those that avoid IRCA's Employment Restrictions, and it appears that none of these lawyers have been prosecuted under IRCA's Encouragement Restriction. This prosecutorial restraint is laudable, but does not provide much comfort. After all, the Henderson court goes to great lengths to question the "dogged consistency" that the government's zeal reflects to pursue the case against a well-meaning employer of an undocu-

${ }^{305}$ See id. at 203-04 (noting that "an unadorned plain meaning reading of the [Encouragement Restriction] can lead to the conclusion that advice about what an [undocumented immigrant] needs to do-including the need for an [undocumented immigrant] to remain in the United States-in order to seek to adjust the [undocumented immigrant's] status could support the conclusion that such advice is within the scope of [the Encouragement Restriction]").

${ }^{306}$ Milavetz, Gallop \& Milavetz, P.A. v. United States, 559 U.S. 229, 231 (2010).

${ }^{307}$ Id. at 239.

${ }^{308}$ Milavetz, Gallop \& Milavetz, P.A. v. United States, 541 F.3d 785, 793 (8th Cir. 2008), aff' d in part, rev'd in part, Milavetz, 559 U.S. 229.

${ }^{309}$ Milavetz, 559 U.S. at 243. 
mented immigrant. ${ }^{310}$ The court heralded the virtues of prosecutorial restraint, quoting Justice Robert Jackson, ${ }^{311}$ Justice Louis Brandeis, ${ }^{312}$ an apocryphal maxim attributed to the Athenian historian Thucydides, and Shakespeare..$^{313}$

The Henderson court's intellectual musings on the appropriate use of power, while impressive, are a bit beside the point. The more concerning issue is not the potential for the government to occasionally exhibit inappropriate zeal, but rather the possibility of chilling protected speech. ${ }^{314}$ For this reason, any responsible analysis of constitutional overbreadth should not consider prosecutorial intent. As noted in Stevens, "the First Amendment protects against the Government; it does not leave us at the mercy of noblesse oblige. We would not uphold an unconstitutional statute merely because the Government promised to use it responsibly." 315 Thus, any lack of prosecutions of lawyers for violations of the Encouragement Restriction is irrelevant. The mere threat of the possibility of such prosecution is enough to recommend striking down the Encouragement Restriction.

\section{B. Rendering State Laws and Policies Ineffective}

A plain reading of the Encouragement Restriction not only has the potential to reach legal advice, but it also threatens a number of state policies and laws. Take, for example, the fact that thirteen states and the District of Columbia currently allow undocumented people to obtain driver's licenses. ${ }^{316}$ These states might consider this necessary for undocumented people to lead more comfortable lives by lessening an ever-present fear of driving without proper documentation. Advocates highlight the fact that many undocumented people

${ }^{310}$ Henderson, 857 F. Supp. 2d at 193-94, 212.

311 See id. at 212 (quoting former U.S. Attorney General Robert H. Jackson who said that "the citizen's safety lies in the prosecutor who tempers zeal with human kindness" (citing Robert H. Jackson, The Federal Prosecutor, 24 J. AM. JUDICATURE SOC. 18, 20 (1940))).

${ }^{312}$ See id. ("Experience should teach us to be most on our guard to protect liberty when the government's purposes are beneficent. . . . The greatest dangers to liberty lurk in insidious encroachment by men of zeal, well-meaning but without understanding." (quoting Justice Brandeis's dissent in Olmstead v. United States, 277 U.S. 438, 479 (1928) (Brandeis, J., dissenting))).

${ }^{313}$ Id. at 213-14 (quoting DANiEL J. KORNSTEIN, Kill ALL THE LAWyERS? SHAKESPEARE’S LEGAL APPEAL 55 (1994)). The court in Henderson mentions that Thucydides stated that "[o]f all manifestations of power, restraint impresses men most." $I d$. at 213 \& n.13 (citing Walter Lippmann, Today and Tomorrow, L.A. TIMES, Jan. 18, 1944, at A4). In addition, the case cites Shakespeare's comment that, "O, it is excellent [ $\mathrm{t}$ ]o have a giant's strength, but it is tyrannous [ $\mathrm{t}$ ]o use it like a giant." Id. at 214 (citing KORNSTEIN, supra, at 55).

${ }^{314}$ See Ashcroft v. Free Speech Coal., 535 U.S. 234, 244 (2002) ("The Constitution gives significant protection from overbroad laws that chill speech within the First Amendment's vast and privileged sphere.").

${ }^{315}$ United States v. Stevens, 559 U.S. 460, 480 (2010).

316 See Mendoza \& Polkey, supra note 129. 
have children who are U.S. citizens, and an inability to obtain a driver's license makes it difficult to take those children to school, doctors, and any number of other necessary activities. ${ }^{317}$ Further, these policies are often justified by focusing on the safety of all drivers, recognizing that an undocumented person with a driver's license is less likely to flee the scene of an accident and is more likely to cooperate with authorities. In Minnesota, for example, a county sheriff highlighted this benefit by testifying that undocumented immigrants "will be less likely to flee the scene if they get in an accident because of their status" and expressed optimism that "it will also make people more comfortable coming to the police for any issues." 318 Advocates for this policy in Wisconsin cite potential benefits to both safety and the economy. ${ }^{319}$ From an economic perspective, advocates note that Wisconsin's 'farms rely on immigrant labor and they're located in rural areas, so really the only way for those peoples' employees to get to work is for them to drive." 320 In terms of safety, advocates emphasize that extending the right for undocumented people to obtain driver's licenses will not only require those drivers to take driving safety tests, but also allow such drivers to obtain car insurance. ${ }^{321}$

317 See Monsy Alvarado, The Pressure Is on to Let Undocumented Immigrants Get NJ Driver's Licenses, USA TODAY NETWORK N.J. (Mar. 4, 2019), https://www.northjersey.com/story/news/newjersey/2019/03/04/push-vote-allow-nj-drivers-licenses-undocumented-immigrants/3015254002/ [https:// perma.cc/J7TS-GCWB] ("In New Jersey, 168,000 children have undocumented parents who cannot drive them to and from school, their doctor's appointments, sports games and practices, and other activities and errands parents make with their children." (quoting a policy analyst from New Jersey Policy Perspective, Erika J. Nava)). California's program, for example, was intended to help undocumented people "drive to work, take their kids to school in the morning or go see the doctor without fear that their car is going to be impounded." Andrea Castillo, California Driver's License Program for Those Here Illegally Surpasses 1 Million Drivers, L.A. TIMES (Apr. 5, 2018), https://www.latimes. com/local/lanow/la-me-dmv-illegal-immigration-licenses-20180404-story.html [https://perma.cc/ Z4PZ-KVKG] (quoting Luis Alejo, the assemblyman who wrote the bill allowing undocumented people to obtain driver's licenses in California).

318 See David Chanen, Hennepin County Sheriff Endorses Bill for Driver's Licenses for Immigrants Here Illegally, STAR TRIB. (Mar. 8, 2019), http://www.startribune.com/hennepin-countysheriff-endorses-bill-for-driver-s-licenses-for-immigrants-here-illegally/506909692/ [https://perma.cc/ PL8Z-JQUT] (quoting Hennepin County Sheriff Dave Hutchinson). The article notes: "[Minnesota] Attorney General Keith Ellison said he backs the legislation as a matter of public safety and 'of helping people live with dignity." 'Id.

${ }^{319}$ Phoebe Petrovic, Evers' Budget Proposes Extending Eligibility for Driver's Licenses, In-State Tuition to Immigrants, WIS. PUB. RADIO (Mar. 5, 2019), https://www.wpr.org/evers-budget-proposesextending-eligibility-drivers-licenses-state-tuition-immigrants [https://perma.cc/4S2U-CDYY] (“[P]ermitting immigrants living in the country without documentation to obtain driver's licenses is both an issue of economic development and public safety." (quoting the Dairy Business Association's director of government affairs, John Holevoet)).

${ }^{320}$ Id. (quoting Holevoet).
${ }^{321} \mathrm{Id}$. 
Although the justifications for the policy share similarities, each state emphasizes different reasons for allowing undocumented people to obtain driver's licenses. As summarized in a report by the Latino Policy Institute:

In Vermont, for example, the legislation to grant driving privileges to the undocumented immigrants of the state made economic sense, because most undocumented immigrants living in Vermont work on dairy farms, which are a substantial contributor to Vermont's economy. Granting the undocumented population in Vermont driving privileges ensured that these workers could get to work. Nevada enacted similar legislation for public safety reasons. The premise of the legislation in Nevada was that issuing driving privileges to the undocumented population would ensure that drivers would have to pass driver's education and driving tests. Nevada also required that recipients of driving privileges purchase car insurance, ensuring the availability of greater resources for accident victims. Colorado's justification for the legislation was that the cost of car insurance premiums will not increase due to losses caused by undocumented immigrants. ${ }^{322}$

Similar arguments are echoed in New York, ${ }^{323}$ Rhode Island, ${ }^{324}$ and Massachusetts. ${ }^{325}$ Regardless of the justifications, a broad construction of the Encouragement Restriction would ignore each of these arguments and could, for example, punish a person for driving an undocumented person to the state agency that issues driver's licenses. Helping them obtain a legal means of moving about the country suggests that the driver would be impermissibly encouraging an undocumented person to stay in the United States. For similar reasons, an insurance agent selling an undocumented person auto insurance might also be prosecuted. Regardless of whether such an outcome is beyond the intended scope of the Encouragement Restriction, these policies represent the type of state laws that might run afoul of a broadly construed Encouragement Restriction.

The examples of state laws and policies that might result in multiple violations of the Encouragement Restriction are not limited to states that permit

322 Deborah Gonzalez ET al., Latino Policy Inst., A Legal and Policy Analysis of DRIVER'S LICENSES FOR UNDOCUMENTED RHODE ISLANDERS 3 (2016).

${ }^{323}$ Kelsey O'Connor, Local Legislators Support Bill to Grant Driver's Licenses Regardless of Immigration Status, ITHACA VOICE (Mar. 6, 2019), https:/ithacavoice.com/2019/03/local-legislatorssupport-bill-to-grant-drivers-licenses-regardless-of-immigration-status/ [https://perma.ce/XY6J-KHZ6].

${ }^{324}$ Steve Ahlquist, Legislation to Allow Undocumented Immigrants Driver's Licenses Introduced., UPRISE RI (Mar. 1, 2019), https://upriseri.com/2019-03-01-drivers-licenses/ [https://perma. $\mathrm{cc} / \mathrm{X} 9 \mathrm{~F} 4-3 \mathrm{KSZ}]$.

${ }^{325}$ Chris Lisinski, Lawmakers Push Bill Making Undocumented Immigrants Eligible for Driver's Licenses, WBUR NEWS (Jan. 23, 2019), https://www.wbur.org/news/2019/01/23/undocumentedimmigrants-drivers-licenses-bill [https://perma.cc/WE8S-A7FN]. 
driver's licenses. For example, there are a number of states that extend in-state tuition benefits to undocumented students. ${ }^{326}$ Some states go further, extending in-state tuition to undocumented people and providing state-financed financial aid and scholarships. ${ }^{327}$ Many of these states require the applicants to have attended middle and high school within the state. ${ }^{328}$ These policies clearly provide an incentive (in-state tuition) for undocumented people to remain in the state (at least for high school and undergraduate study). Consider the following examples of benign actions that would arguably violate the Encouragement Restriction: a high school counselor explaining in-state tuition benefits to undocumented students who aspire to go to college; a well-meaning neighbor encouraging a high school student to continue to reside in a particular state, in order to maintain the potential in-state tuition benefit; and a college financial aid advisor who identifies the state financial aid packages available to undocumented students. Each of these activities would appear to be a clear case of impermissible encouragement, even though they are furthering a state policy.

Beyond driver's licenses and higher education benefits, a broadly construed Encouragement Restriction might also interfere with workers' compensation laws that classify undocumented workers as employees in the event the person is injured on the job. ${ }^{329}$ To justify the inclusion of undocumented people under the protections of workers' compensation laws, advocates note that "Latino workers, including both immigrants and non-immigrants, suffer fatal

${ }^{326}$ See, e.g., CAL. EDUC. CODE $\$ 68130.5$ (West 2018) The bill was passed as Assembly Bill 540 and signed into law in 2001. There are at least nineteen states that extend in-state tuition benefits to undocumented people.

${ }^{327}$ Ashley A. Smith, Promoting Tuition-Free Programs to Undocumented Students, INSIDE HIGHER ED (Mar. 12, 2019), https://www.insidehighered.com/news/2019/03/12/more-states-are-encouragingundocumented-students-pursue-tuition-free-programs [https://perma.cc/SF9N-QL4N]. The article notes:

Maryland, which is starting its Promise Scholarship program this year, and New York, which passed legislation in January to extend state aid to undocumented students, are the latest states to join California, Delaware, Oregon, Rhode Island and Washington in offering financial aid and grants or scholarships to students who live in those states but lack legal-immigrant status.

Id.

${ }^{328}$ See Jeremy Bauer-Wolf, An Assist for DACA Students, InSIDE Higher Ed (Aug. 9, 2019), https://www.insidehighered.com/news/2019/08/09/new-michigan-state-tuition-requirements-helpundocumented-daca-students [https://perma.cc/5YES-K48A] ("Under the new policy, students can establish their residency in Michigan, and thus qualify for in-state tuition, by attending a middle school in the state for at least two years. They then must earn a GED or graduate from an in-state high school that they attended for at least three years.").

${ }^{329}$ DEBORAH BERKOWITZ, NAT'L EMP'T LAW PROJECT, UNINTENDED CONSEQUENCES OF LIMITING WORKERS' COMP BENEFITS FOR UNDOCUMENTED WORKERS 1 (2017), https://www.nelp.org/ publication/unintended-consequences-limiting-workers-comp-benefits-undocumented-workers/ [https://perma.cc/8E5Y-Z8N8] ("Almost all states either explicitly or implicitly include undocumented workers in their workers' compensation statutes."). 
workplace injuries at an alarmingly higher rate than other workers in the U.S. workforce." ${ }^{330}$ If states were to exclude undocumented people from workers' compensation protections, they would effectively "encourage unscrupulous employers to hire undocumented workers and then use their immigration status as a shield to escape full responsibility for on-the-job injuries." ${ }^{331}$ By way of example, Case Farm, one of the largest poultry companies in the country,

built its business by recruiting some of the world's most vulnerable immigrants, who endure harsh and at times illegal conditions that few Americans would put up with. When these workers have fought for higher pay and better conditions, the company has used their immigration status to get rid of vocal workers, avoid paying for injuries, and quash dissent. ${ }^{332}$

Thus, there are a multitude of consequences that will potentially flow from a broad construction of the Employment Restriction.

\section{Public Universities and Private Corporations}

A number of private entities, public institutions, and individual U.S. citizens currently engage in activities that could conceivably be covered by the Encouragement Restriction. With respect to public institutions, consider the following statement: "The University of Michigan encourages the application and enrollment of undocumented students-as well as students who receive benefits under the Deferred Action for Childhood Arrivals (DACA) programwho are academically excellent and accomplished in extracurricular endeavors." ${ }^{333}$ Similar policies can be found on public university websites across the country. ${ }^{334}$ To justify these policies, University of Michigan President Mark

${ }^{330} \mathrm{Id}$.

${ }^{331}$ See id. ("That would give employers who cheat an unfair advantage over employers who play by the rules. States should not create financial incentives to ignore health and safety laws.").

${ }^{332}$ Grabell, supra note 181.

${ }^{333}$ See Undocumented Students, U. Mich., https://admissions.umich.edu/undoc-students [https:// perma.cc/UFV9-HLP5]. DACA provided temporary protection from deportation for certain undocumented people. See Deferred Action for Childhood Arrivals (DACA), DEP'T HOMELAND SECURITY, https://www.dhs.gov/deferred-action-childhood-arrivals-daca [https://perma.cc/TL7K-CQH7].

${ }^{334}$ See, e.g., Undocumented Students-All Students Welcome at UConn, UCONN OFFICE OF STUDENT FIN. AID SERVS., https://financialaid.uconn.edu/undocumented_students/\# [https://perma.cc/ 8B49-TDZ8]. The university's website notes:

The University of Connecticut encourages all academically accomplished students who are ready to take the next step in reaching their higher educational goals to apply for admission, regardless of citizenship status. This includes students who may just be learning their immigration status for the first time during the college admissions process. Admission to the University is based on a holistic approach which includes grade 
Schlissel said undocumented students "enrich" the University of Michigan's community with their "many talents, hard work, and the diverse perspectives and life experiences." "335 Such a statement, a laudatory pronouncement that the school would like undocumented students to apply and attend a particular school, would likely violate a broadly construed Encouragement Restriction. After all, this statement literally encourages ("The University of Michigan encourages") undocumented immigrants to apply to college. Combined with the fact that around ninety-seven percent of the freshmen reside on campus, this statement clearly encourages an undocumented person to reside in the United States. Given that a number of schools have similarly placed a high value on undocumented students, it seems like a poor policy decision to enforce a law that would make it impossible to recruit such students. ${ }^{336}$

A broad construction of the Encouragement Restriction also potentially affects the actions of private businesses. For example, in the face of the Trump Administration's threats to end the DACA program, a number of companies spoke out to support renewal of the program. ${ }^{337}$ The President of Microsoft famously said that if the government wanted to deport Microsoft employees

point average, class rank, SAT or ACT score, required essay, extracurricular activities, and optional letters of recommendation.

Id.

335 Protecting the Interests of Our International Community of Scholars, U. MiCH. (Jan. 28, 2017), https://president.umich.edu/news-communications/on-the-agenda/protecting-the-interests-ofour-international-community-of-scholars/ [https://perma.cc/TBR2-YDQW]; Statement on DACA from President Mark Schlissel, U. Mich. OfFICE OF THE PRESIDENT, (Sept. 3, 2017), https://president. umich.edu/news-communications/statements/statement-on-daca-from-president-mark-schlissel/ [https://perma.cc/5ZYN-ME5Z].

${ }^{336}$ In a similar vein, it is likely that the Encouragement Restriction might hinder private organizations from providing scholarships for undocumented students. It is hard to imagine how the provision of scholarship funds, which may be used not only for tuition and books, but also room and board (i.e., residence), could be considered anything less than encouragement of undocumented people to reside in the United States. See, e.g., PepsiCo Cesar Chavez Latino Scholarship, CeSAR Chavez Found., https://chavezfoundation.org/CCF_scholarship [https://perma.cc/3BH8-SL5R] (describing the Chavez Foundation's PepsiCo Cesar Chavez Latino Scholarship Fund that "provides $\$ 300,000$ in scholarship awards to qualified Latino students in Arizona and California regardless of national origin or immigration status in an effort to promote their academic success"); Undocupoets, SIBLING RIVALRY PRESS, https://www.siblingrivalrypress.com/undocupoets-fellowship/ [https://perma.cc/94MB-ATG3] (describing its fellowship providing a cash award to undocumented poets); What Should I Know?, GOLDEN DOOR SCHOLARS, https://www.goldendoorscholars.org/future-scholars [https://perma.cc/23M9TNQX] (stating that the organization "lights the way for [DACA] Dreamers to invest in their education and to achieve their career goals beyond what they might imagine").

${ }^{337}$ Joseph Hincks, CEOS from More Than 400 Leading U.S. Companies Urge Trump to Keep DACA, FORTUNE (Sept. 5, 2017), https://fortune.com/2017/09/05/daca-trump-dreamers-businessleaders/ [https://perma.cc/T7LF-48P8] ("Some of America's largest companies have thrown their weight behind a campaign urging President Donald Trump not to scrap an Obama-era program that protects undocumented immigrants who were brought to the United States as children from being deported.”). 
with DACA status, "it's going to have to go through us." ${ }^{338}$ It is reasonable to assume that this statement, however intended, encouraged any undocumented Microsoft employees, in that it would fill them with hope. Such hope might reasonably lead undocumented people to continue to reside in the United States, comfortable in the knowledge that their employer promised to protect them. As such, the statement violates the plain meaning of the Encouragement Restriction.

As further evidence of the reach of this statute, consider the fact that the Encouragement Restriction not only affects Microsoft, one of the largest companies in the U.S., but also organized labor. A number of unions have begun to provide support to their undocumented members. For example, the Painters Union Local 82 secured an attorney for Hugo Mejía Murguía, an undocumented union member, when Mr. Murguía was detained by Immigration and Customs Enforcement (ICE). ${ }^{339}$ Not content to stop with legal representation, the union "went all out on his behalf, holding rallies around the country to stop his deportation," ultimately resulting in public pressure that led to Mr. Murguía receiving relief from deportation. ${ }^{340}$ To the extent such activity might not amount to encouragement, take note of Mr. Murguía's statement: "A couple times I tried to quit. It was just so hard to stay far from my family. . . . When [the union] gave me letters and this support, that got me excited and I didn't feel so alone about my case." ${ }^{441}$ The activities of the union in Mr. Murguía's case clearly meet the dictionary definition of encouragement often used by courts: "to inspire with courage, spirit, or hope." Further, this is not an isolated event, as many unions have taken steps to advocate for their undocumented members. ${ }^{342}$

Finally, consider the effect that a robust Encouragement Restriction might have on people who live near or in municipalities or states that have publicly fought federal efforts to use local law enforcement to enforce federal immigration law. Generally speaking, these efforts, often referred to as "sanctuary" laws, "restrict cooperation between local law enforcement and federal immi-

${ }^{338}$ Aarti Shahani, Microsoft President to Trump: To Depont a DREAMer, You'll Have to Go Through Us, NPR (Sept. 5, 2017), https://www.npr.org/sections/thetwo-way/2017/09/05/548686695/ 250-apple-employees-among-thousands-at-risk-from-daca-cancellation [https://perma.cc/DR6J-DBSN].

${ }^{339}$ Mike Elk, Undocumented Workers Find New Ally as Unions Act to Halt Deportations, THE GUARDIAN (Mar. 22, 2018), https://www.theguardian.com/us-news/2018/mar/22/unions-undocumentedworkers-immigration-deportation-painters [https://perma.cc/GW79-PHQY].

${ }^{340}$ See id. ("Finally, on 22 November, after 204 days in detention, he was released as a result of his union's activism in public and in court, winning a stay on political asylum grounds.").

${ }^{341} I d$.

342 See, e.g., Alvarado, supra note 317 (discussing the fact that in New Jersey, "13 leaders of labor unions across the state sent a letter to Gov. Phil Murphy, state Senate President Stephen Sweeney ... and [Assembly Speaker] Coughlin . . lobbying for them to take action on the measure" to permit undocumented people to obtain driver's licenses). 
gration authorities by denying ICE access to jails or not complying with detainer requests." ${ }^{343}$ Thus, if local law enforcement held an undocumented immigrant for a minor offense, they might receive a request to detain the individual until federal immigration authorities could assume custody. Sanctuary laws provide explicit permission for the local authority to ignore such requests. Given the potential emotional devastation of losing a family member to deportation for something as minor as driving without a license (especially if the person lives in a state that does not issue licenses to undocumented people), it is not far-fetched to assume that well-meaning people might encourage undocumented families to relocate to a nearby sanctuary city. Imagine turning to an undocumented friend and saying: "You know, you should really consider moving to Nevada, because then at least you could get a driver's license. I'd be happy to help with the moving costs." Such a simple, well-meaning act might be considered unlawful encouragement under a broad reading of the Encouragement Restriction.

\section{CONCLUSION}

Despite the uncertain reach of IRCA's Encouragement Restriction, transactional lawyers across the country provide invaluable legal advice to undocumented people in an effort to help them achieve financial stability. If IRCA's Encouragement Restriction were to discourage this legal advice, it would rob many undocumented people of their best financial option, deprive federal, state, and local governments of a powerful revenue source, and further incentivize unscrupulous employers to exploit the vulnerability of undocumented workers. Further, a broad reading of the Encouragement Restriction might negatively affect a number of socially productive activities. The Ninth Circuit's decision to strike down IRCA's Encouragement Restriction was sound from a doctrinal perspective, in that it refused to engage in a statutory interpretation that amounts to re-writing the statute. But more importantly, it represents good policy. The decision was a breath of fresh air for the many advocates, lawyers, family members, and friends who daily engage in activity that might be perceived as unlawful encouragement.

${ }^{343}$ Christina Goldbaum, State Courts Become Battleground Over Trump's Sanctuary Cities Policy, N.Y. TIMES (Dec. 12, 2018), https://www.nytimes.com/2018/12/12/nyregion/sanctuary-cities-statecourts.html [https://perma.cc/2KYU-Q94B]; see also Christopher N. Lasch et al., Understanding "Sanctuary Cities," 59 B.C. L. REv. 1703, 1713-19 (2018) (discussing the Trump Administration's pursuits to end sanctuary cities). 